
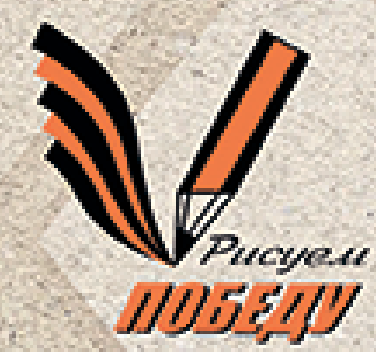

НРАВСТВЕННО-ЭСТЕТИЧЕСКОЕ

И ГРАЖДАНСКО-ПАТРИОТИЧЕСКОЕ ВОСПИТАНИЕ

В ГОСУДАРСТВЕННЫХ УЧРЕЖДЕНИЯХ ОБРАЗОВАНИЯ И КУЛЬТУРЫ

\title{
TOM III
}

Материалы Всероссийской научно-практической конференции «Рисуем Победу-2021» 
БОУ ВО Чувашской Республики

«Чувашский государственный институт культуры и искусств»

Министерства культуры, по делам национальностей и архивного дела Чувашской Республики

Государственное бюджетное учреждение культуры города Москвы «Централизованная библиотечная система

Западного административного округа»

\section{НРАВСТВЕННО-ЭСТЕТИЧЕСКОЕ И ГРАЖДАНСКО-ПАТРИОТИЧЕСКОЕ ВОСПИТАНИЕ В ГОСУДАРСТВЕННЫХ УЧРЕЖДЕНИЯХ ОБРАЗОВАНИЯ И КУЛЬТУРЫ}

\section{TOM III

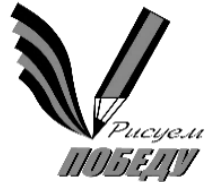

Материалы Всероссийской научно-практической конференции «Рисуем Победу-2021»

Москва - Чебоксары

2021 
УДК 37.03

ББК 74.200

H86

Рецензенты:

B. А. Васильев, доктор культурологии, профессор

Г. М. Гогиберидзе, доктор педагогических наук, профессор

И. В. Кожанов, доктор педагогических наук, доцент

Редактор-составитель:

В. С. Головачев

Редакционная коллегия:

А. И. Аршинова, Н. И. Баскакова, В. С. Головачев, О. А. Орлова, Ю. В. Пранулис

Печатается по решению Ученого совета Чувашского государственного института культуры и искусств» и Централизованной библиотечной системы Западного административного округа

Нравственно-эстетическое и гражданско-патриотическое воспитание в госуH86 дарственных учреждениях образования и культуры : материалы Всероссийской научно-практической конференции «Рисуем Победу» (Москва, 2021 г.) / под ред. В. С. Головачева. - Чебоксары : Издательский дом «Среда», 2021. T. 3. $-112 \mathrm{c}$.

В сборнике размещены тезисы выступлений участников Всероссийской научно-практической конференции «Рисуем Победу-2021». Ведущие специалисты учреждений образования и культуры представляют свой методический опыт организации и проведения масштабных проектов, акций, мероприятий гражданско-патриотической тематики.

Для преподавателей средних учебных заведений и детских школ искусств.

ISBN 978-5-907411-68-5

УДК 37.03

DOI 10.31483/a-10327

ББК 74.200

(С БОУ ВО ЧР «ЧГИКИ» Минкультуры Чувашии, 2021 


\section{СОДЕРЖАНИЕ}

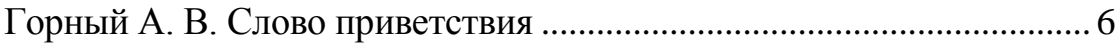

Аршинова А. И. Слово приветствия .......................................... 7

Баскакова Н. И. Слово приветствия..................................................... 8

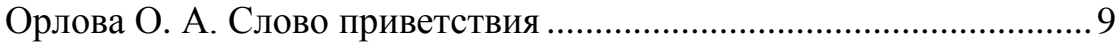

Кожанов И. В. Слово приветствия................................................ 10

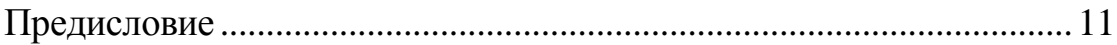

Гогиберидзе Г. М., Скрынник М. А. Специфика патриотического воспитания детей в условиях библиотечной системы .............................. 16

Кожанов И. В., Головачев В. С. Нравственно-эстетическое воспитание дошкольников в формате сетевого онлайн-проекта.............22

Комарова И. И., Комарова Т. С., Третьяков А. Л. Художественноэстетическое воспитание в современном дошкольном детстве..............229

Никольская Е. В. Духовно-нравственное воспитание студентов педагогических вузов средствами фольклора ........................................... 39

Алексеева Л. Ю., Янова С. В. Становление нравственно-ценностных отношений у детей младшего дошкольного возраста в условиях игровой деятельности ..... 46

Евстафьева С. А., Евстафьева К. С. Гражданско-патриотическое воспитание дошкольников на основе проектного метода ........................50

Третьяков А. Л. Психолого-педагогические основы развития детей старшего дошкольного возраста ..............................................................54

Куланина И. Н. Некоторые аспекты духовно-нравственного

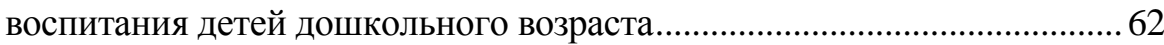

Суркова О. В. Проектная деятельность в детской школе искусств как средство духовно-нравсвенного воспитания молодого поколения

Жукова Г. Е. Методы, формы и средства нравственного воспитания детей дошкольного возраста .74

Суворова В. Н. Метаметодический подход в реализация проектов гражданско-патриотической направленности в образовательной организации 80

Зимина Л. Г. Гражданско-патриотическое воспитание обучающихся в МУ ДО «Радуга» КГО Челябинской области 
Третьяков А. Л. Проектная деятельность в экологическом образовании старших дошкольников .................................................... 91

Курдявцева К. Л. Воспитание гражданственности и духовнонравственного наследия через осознанное восприятие исторического

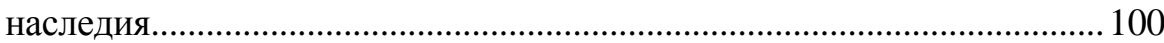

Цыпкина У. А. Растим детей патриотами ......................................... 104 Бондарь О. А. Из опыта подготовки участников Всероссийской акции «Рисуем Победу» 108 


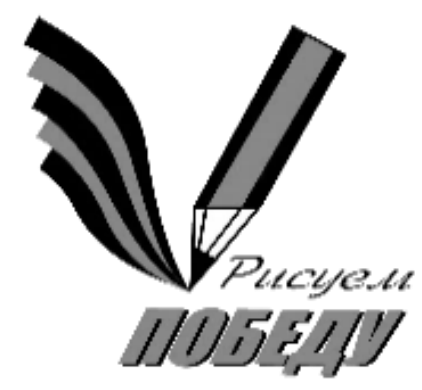

Всероссийская детско-юношеская патриотическая акция «РИСУЕМ ПОБЕДУ-2021» 


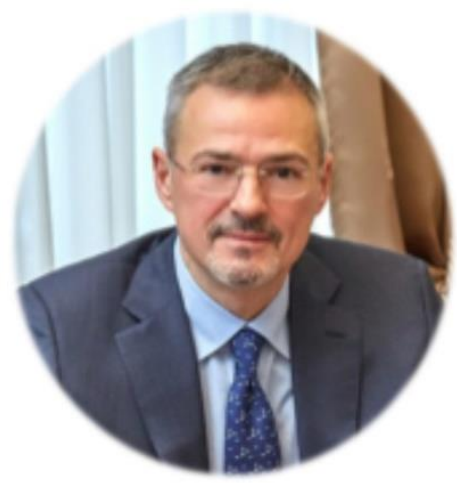

\section{Горный А. В.,} директор Департамента культуры

Министерства обороны

Российской Федерации

Сердечно приветствую участников Всероссийской детско-юношеской акции «Рисуем Победу»!

Этот проект, успешно реализуемый почти десять лет, неизменно объединил юное поколение мальчишек и девчонок, поколение наследников победителей. Конкурсанты представили свои лучшие работы о подвигах и судьбах защитников Отечества, о войне и Победной весне 1945 года. Детские рисунки и эссе поистине честны и наполнены особенной искренностью и жизненной энергией.

Сложно отыскать человека, чью семью Великая Отечественная война обошла стороной. Миллионы наших соотечественников отдали свои жизни ради победы и нам нельзя забывать о том, какой ценой завоевывалось мирное небо над головой.

Выражаю огромную благодарность организаторам этой замечательной творческой инициативы за уникальную возможность сохранения памяти о Великой Победе. 9 мая - священный праздник для потомков тех, кто одержал победу над фашизмом.

Друзья, пусть великие подвиги дедов и прадедов никогда не будут забыты, а война никогда нас не коснется и над нашей страной будет мирное небо. Желаю здоровья, мира, творческого вдохновения и ярких впечатлений! 


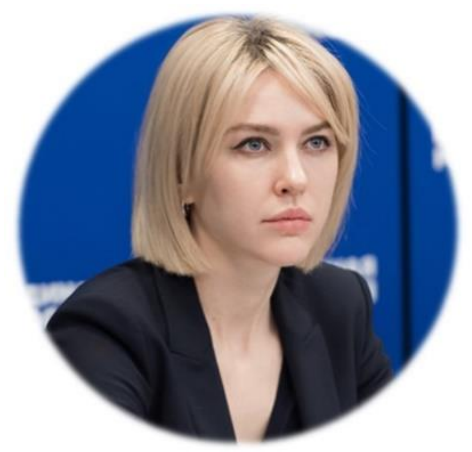

Аршинова А. И.,

куратор Всероссийской акции

«Рисуем Победу», депутат Государственной Думы ФС РФ, кандидат политических наук.

Нравственно-эстетическое и гражданско-патриотическое воспитание - это фундаментальная основа формирования личности человека и гражданина своей страны. В условиях современной геополитической нестабильности, воспитания патриота своего Отечества, человека, умеющего созидать и восхищаться прекрасным, мыслить и рефлексировать - важнейшая задача для государственных учреждений образования и культуры.

Все большую значимость и актуальность принимают формы межведомственного взаимодействия, объединения потенциала профессиональных коллективом и методических наработок учреждений сферы образования и культуры на основе совместных проектных инициатив.

Всероссийская акция «Рисуем Победу», обращенная к самым юным гражданам нашей страны - воспитанникам детских садов, школьникам уже не первый год объединяет сотни учреждений и тысячи участников по всей стране. В ходе проведения акции, воспитателями и учителями, педагогами дополнительного образования и сотрудниками учреждений культуры были представлены значимые авторские разработки в сфере нравственно-эстетического и гражданско-патриотического воспитания. Настоящий сборник включает в себя лучшие примеры подобных проектов и методических разработок. Уверена, что опубликованные материалы будут полезны и интересны специалистам, найдут широкое практическое применение! 


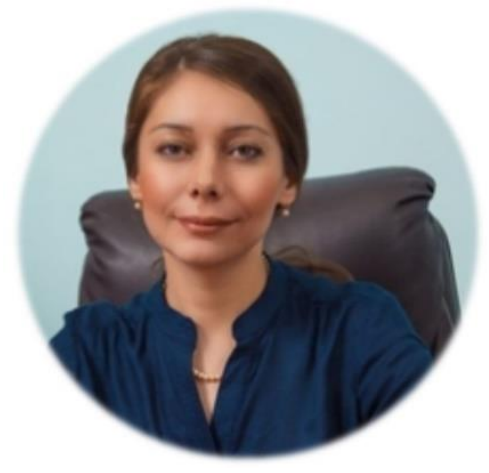

\author{
Баскакова Н. И., \\ ректор Чувашского государственного \\ института культуры и искусств, \\ кандидат философских наук
}

Основой всесторонне развитой личности, гражданина своей Родины является нравственно-эстетическое и гражданско-патриотическое воспитание детей и молодежи. В этом ключе учреждения сферы образования и культуры несомненно играют важную роль. Ежегодно учреждения сферы образования и культуры по всей России принимают активное участие в подготовке и проведении Всероссийской акции «Рисуем Победу».

Бессменным куратором данной Акции является депутат Государственной Думы Алена Игоревна Аршинова, главным организатором, идейным вдохновителем - директор Детской библиотеки им. Бианки г. Москвы Владимир Сергеевич Головачев. Всероссийская акция посвящена теме Великой Отечественной войны. Благодаря данной Акции юные участники чувствуют свою сопричастность к Великой истории нашего народа, его мужеству и стойкости перед ликом страшной войны, его стремлению отстоять право на жизнь будущих поколений. Это безусловно способствует формированию твердой гражданской позиции, уважения к истории, любви к своей Родине и бесконечной благодарности нашим предкам за мирное небо над головой.

Акция имеет широкий охват не только в России, но и за рубежом, насчитывая 531779 тысяч юных участников, что доказывает несомненный интерес молодого поколения к истории Отечества. В этом сборнике собраны лучшие наработки по нравственно-эстетическому и гражданскопатриотическому воспитанию детей и подростков. Уверена, что данные материалы, включающие опыт проведения подобных акций, несомненно будут полезны широкому кругу читателей! 


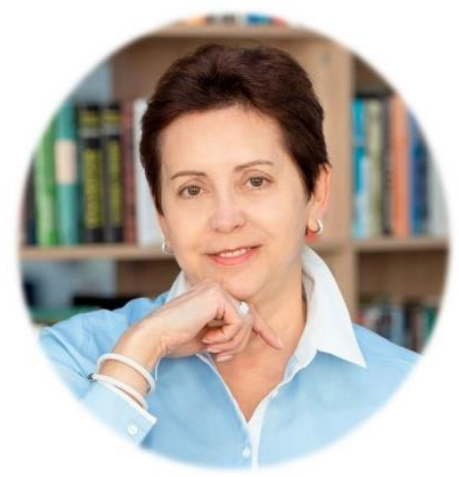

\author{
Орлова О. А., \\ генеральный директор Централизованной \\ библиотечной системы Западного адми- \\ нистративного округа Москвы, \\ заслуженный работник культуры РФ
}

Ежегодно, более 250 публичных библиотек России принимают активное участие в подготовке и проведении Всероссийской детско-юношеской патриотической акции «Рисуем Победу». Библиотеки становятся не только площадками распространения информации об Акции и сбора творческих работ, но и креативными центрами внедрения новых технологичных подходов к реализации этого масштабного проекта.

Так, сотрудники Библиотек Запада Москвы внедрили в работу и ежегодно совершенствуют интернет-портал «Рисуем Победу», который заметно облегчил алгоритм участия в Акции, а учитывая вызовы и ограничения, продиктованные пандемией, сделал возможным само проведение Акции в онлайн-формате.

В настоящем сборнике приводятся теоретические разработки и результаты практической реализации Акции в учреждениях, в том числе, библиотечного типа. Обобщать и популяризировать подобный опыт очень важно для дальнейшего развития и совершенствования современных подходов ведения нравственно-эстетического и гражданскопатриотического воспитания детско-юношеской аудитории на базе государственных учреждений культуры и образования. 


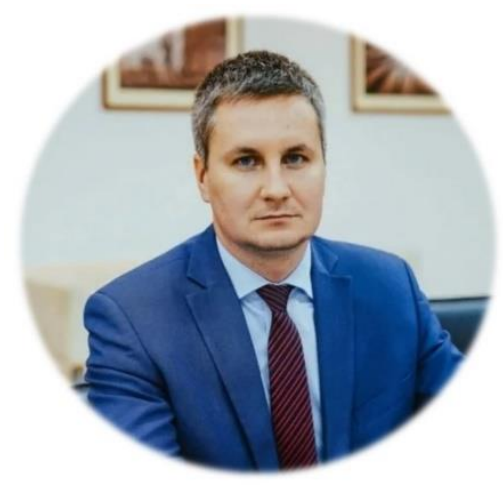

Кожанов И. В., проректор по научной и инновационной работе Чувашского государственного педагогического университета им. И. Я. Яковлева, доктор педагогических наук, доцент

Формирование личности человека как гражданина, патриота своей Родины является основополагающим для безопасности Российской Федерации, консолидации ее многонационального народа.

Достижение данной цели невозможно вне нравственно-эстетического и гражданско-патриотического воспитания подрастающего поколения, неотъемлемой частью которого является обращение к истории и культуре родного народа и страны, диалогу поколений, традициям семьи, когда нравственные идеалы семейного воспитания переходят в этнические и общекультурные ценности.

Значительную роль в становлении личности ребенка играют учреждения образования и культуры, которые все чаще выступают эффективными платформами для межведомственного взаимодействия и реализации значимых проектов как регионального, так и федерального масштабов.

Одним из подобных проектов является ежегодная Всероссийская детско-юношеская патриотическая акция «Рисуем Победу», частью которой является удачная практика обобщение и распространение лучших методических разработок сотрудников учреждений образования и культуры в области гражданско-патриотического и нравственно-эстетического воспитания. Результаты научных изысканий специалистов, их практической реализации в работе с детьми представлены в данном сборнике, готовы для внедрения и тиражирования на всю страну. 


\section{ПРЕДИСЛОВИЕ}

В соответствии с вызовами современной геополитики, внешними и внутренними попытками фальсификации истории, а также ключевыми поправками к Конституции России, предложенными Президентом РФ в послании Федеральному собранию 15 января 2020 г., закрепляющими обязанность чтить память защитников Отечества, отстаивать историческую правду (часть 3 статьи 67), сохранять память предков, преемственность в развитии Российского государства, исторически сложившееся государственное единство (часть 2 статьи 671), в рамках реализации проекта «Новая школа» продолжается реализация масштабной ежегодной гражданско-патриотической акции «Рисуем Победу».

Целью акции является формирование и развитие у детей и молодежи чувства патриотизма, уважения и сопричастности к славному ратному и гражданскому подвигу предков. В процессе творчества, на основе услышанного и осознанного исторического материала, участники вовлекаются в живой диалог поколений, узнают и осознают историю своей семьи и своей страны.

Лучшие методические разработки сотрудников учреждений культуры и образования, разработанные и внедренные в ходе подготовки участников ежегодной Всероссийской детско-юношеской патриотической акции «Рисуем Победу» с 2019 г. издаются в формате научно-методического сборника «Нравственно-эстетическое и гражданско-патриотическое воспитание в государственных учреждениях образования и культуры».

Третий том сборника включил материалы, подготовленные в рамках девятой акции «Рисуем Победу-2021», которая стала наиболее масштабной по охвату и географии участников за все годы проведения. В настоящем сборнике размещены тезисы выступлений участников Bceроссийской научно-практической конференции «Гражданско-патриотическое воспитание в учреждениях образования и культуры».

Ведущие специалисты учреждений образования и культуры представляют свой методический опыт организации и проведения масштабных проектов, акций, мероприятий гражданско-патриотической тематики.

Вопросы нравственно-эстетического и гражданско-патриотического воспитания являются ключевыми на всех этапах становления и развития человеческого общества. Особую актуальность обращение к идеа- 
лам нравственности, эстетики и патриотизма приобретает в современных условиях глобализации, попыток пересмотра фундаментальных общечеловеческих ценностей: института семьи, отношения к Родине, классического наследия мировой культуры и искусства фундаментальной науки и образования.

Государственные учреждения образования (дошкольные учреждения, общеобразовательные школы) и государственные учреждения культуры (публичные библиотеки, музеи, культурно-досуговые центры) начинают занимать все более значимое место в мире детства и юношества.

Эффективной платформой подобного межведомственного взаимодействия (в том числе виртуального), может стать совместная проектная деятельность по средствам объединения потенциала учреждений образования и культуры на основе территориальной близости или общего видения решения прикладных задач нравственно-эстетического воспитания.

В текущем году старт акции был дан 23 февраля 2021 г., в День защитника Отчества, прием работ завершился 1 мая 2021 г., итоги были подведены 9 мая 2021 г., в День Победы. Прием творческих работ (рисунков, эссе) осуществлялся через сайт акции www.risuem-pobedu.ru, обладающий удобной формой загрузки, информационными, просветительскими и справочными материалами. Презентационные уроки, посвященные участию в акции, проводились как в очном, так и в онлайн-формате.

Учитывая новые вызовы суверенитету России, внешние попытки вмешательства во внутренние дела государства, факты распространения заведомо ложных сведений о ветеранах Великой Отечественной войны, отдельные попытки реабилитации нацизма, вовлечение в противоправную деятельность детей и молодежи, а также в свете предложений законопроекта № 1093689-7 «О внесении изменений в отдельные законодательные акты Российской Федерации в части совершенствования мер, направленных на увековечение памяти погибших при защите Отечества и защиту исторической памяти», планируется вывести акцию на новый уровень охвата аудитории и географии участников.

В учреждениях образования (в том числе дошкольной ступени), культуры и молодежной политики проведены тематические занятия, посвященные широкому участию в акции. Активное позиционирование акции в сети интернет сопровождалось активизацией тематического контента в социальных сетях, продвижению хештега \#РисуемПобеду. 
Дополнительное внимание уделено работе с зарубежными участниками, в особенности, из государств СНГ. На участие в акции приняты работы юных граждан Белоруссии, Казахстана, Армении, Узбекистана, Киргизии и других государств.

Партнерами акции выступили: департамент культуры Министерства обороны Российской Федерации, Центральный музей Победы, ФГБУ «Роспатриотцентр», РИА «ПобедаРФ». Опорными площадками стали учреждения культуры, образования и молодежной политики регионов России.

В настоящий момент акция охватила все регионы России, а также государства ближнего и дальнего зарубежья. Юным участникам акции предлагается создать рисунок, а также, побеседовав со старшими написать краткое эссе, рассказывающее о жизни судьбе родных и близких в годы войны.

С 2019 г. акция реализуется на базе специально созданной интернетплатформы www.risuem-pobedu.ru, обеспечивающей удобное участие для удаленных пользователей. Разработанный ресурс стали результатом совместной работы коллективов учреждений образования, культуры и молодежной политики регионов России в рамках федерального партийного проекта «Новая школа». Была разработана модель эффективного межведомственного взаимодействия, учитывающая специфические возможности учреждений, необходимые для реализации проекта, их образовательный, научно-методический и творческий потенциал.

До 2018 г. акция проводилась в очном формате (смотры-конкурсы детского творчества в образовательных учреждениях), с 2019 г. - в гибридном (подача заявок через интернет-платформу, награждение финалистов и итоговые выставки - в очном формате), с 2020 г. - в целях безопасности участников и исключения дополнительных рисков здоровью, в онлайн-формате.

Созданная интернет-платформа позволяет собирать, систематизировать и хранить в электронном виде, на постоянной основе произведения детского творчества, посвященные теме Великой Отечественной войны и сопутствующие методические, исторические, справочные и интерактивные материалы.

Потенциальной аудиторией сайта являются учащиеся школ в возрасте от восьми до 16 лет, студенты, учителя, преподаватели, методисты, педагоги-организаторы, сотрудники учреждений культуры, члены молодежных общественных организаций, волонтеры. Интерактивными 
ресурсами сайта могут пользоваться и дошкольники в сопровождении родителей или воспитателя.

Графическое оформления сайта стилизовано под полевую сумкупланшет фронтового художника (кнопки и опции представлены карандашами, накладными карманами, атрибутами военного быта. Окна меню - фронтовыми картами, полевыми блокнотами, «треугольниками» фронтовой почты).

Наиболее высокие по охвату и заинтересованности аудитории результаты показали регионы, в которых непосредственное руководство акцией осуществлялось региональными кураторами проекта «Новая школа»: Москва (координатор В. Е. Бондаренко), Республика Карелия (координатор Г. А. Гореликова), Санкт-Петербург (координатор Ю. А. Мартемьянова).

Механизм реализации проекта отражен в следующих монографиях, методических рекомендациях и статьях:

1. Аршинова, А. И. Возможности межрегионального проектного взаимодействия учреждений образования и культуры в нравственно-эстетическом воспитании дошкольников / А. И. Аршинова, В. С. Головачев // Вестник Чувашского государственного педагогического университета им. И. Я. Яковлева. - 2019. - № 5. - С. 143-151.

2. Аршинова, А. И. Всероссийская акция «Рисуем Победу» : методические рекомендации / А. И. Аршинова, В. С. Головачев. - Чебоксары : Издательский дом «Плакат», 2019. - 60 с.

3. Головачев, В. С. Межведомственная интеграция в нравственноэстетическом воспитании дошкольников практика / В. С. Головачев // Непрерывное образование: XXI век. - 2019. - № 2. - С. 142-151.

4. Головачев, В. С. Нравственно-патриотическое воспитание детей младшего возраста в условиях межведомственного взаимодействия (из опыта проведения Всероссийской акции «Рисуем Победу») / В. С. Головачев // Сборник трудов участников Всероссийской научно-практической конференции «Рисуем Победу-2019». - 2019. - С. 26 - 32.

5. Головачев, В. С. Опыт сетевого взаимодействия учреждений образования и культуры в нравственно-патриотическом воспитании дошкольников / В. С. Головачев // Духовно-нравственное и патриотическое воспитание молодежи. - Чебоксары : Плакат, 2020. - С. 74-79.

6. Головачев, В. С. Организация проектной деятельности в условиях взаимодействия образовательных комплексов и учреждений культуры 
/ В. С. Головачев // Воспитание и обучение: теория, методика и практика. - Чебоксары, 2018. - С. 103-105.

7. Golovachev, V. S. Model of interaction between libraries and preschool educational institutions in terms of the moral and aesthetic education of preschool children / V. S. Golovachev, M. B. Zatsepina // Перспективы науки и образования. - 2020. - № 5. - С. 102-119.

Редакционная коллегия сборника. 
Гогиберидзе Г. М.,

доктор педагогических наук, профессор кафедры философии и социальных наук, Московский городской педагогический университет

Скрынник М. А., аспирант кафедры философии и социальных наук, член организационного комитета Всероссийской детско-юношеской акции «Рисуем Победу», Московский городской педагогический университет

\section{СПЕЦИФИКА ПАТРИОТИЧЕСКОГО ВОСПИТАНИЯ ДЕТЕЙ В УСЛОВИЯХ БИБЛИОТЕЧНОЙ СИСТЕМЫ}

Аннотация. В статье рассматривается ход и результаты комплексного исследования современных технологий гражданско-патриотического воспитания учащихся в образовательно-воспитательном пространстве. В процессе исследования проблемы использовались методы логического, статистического анализа. Основываясь на предыдущем опыты, работники российских библиотек четко осознали, что патриотизму нельзя научить, ему надо постепенно воспитывать. Библиотеки в новых условиях развития и реформирования системы отечественного образования должны применять инновационные формы и методы организации патриотического воспитания, используя весь свой потенциал. К работе библиотек по историко-патриотическому и духовному воспитанию должны активно привлекаться специалисты других сфер, не только педагоги.

Ключевые слова: патриотизм, патриотическое воспитание, библиотечная система.

Gogiberidze G. M., Doctor of Pedagogical Sciences, Professor of the Department of Philosophy and Social Sciences, Moscow City Pedagogical University

Skrynik M. A., postgraduate student of the Department of Philosophy and Social Sciences, member of the organizing Committee of the All-Russian children's and youth action "Draw a Victory", Moscow City Pedagogical University

\section{SPECIFIC PATRIOTIC EDUCATION OF CHILDREN IN THE CONDITIONS OF THE LIBRARY SYSTEM}

Abstract. In our time of universal computerization and the Internet, libraries remain the main link in the formation and education of the individual. Indeed, despite the new technical capabilities, the book remains the main 
source of knowledge, and the ability to read is the main quality of an educated person. In this regard, the patriotic education of children and youth in libraries is becoming an important element in the organization of the educational process. Based on previous experiences, the workers of Russian libraries have clearly realized that patriotism cannot be taught, it must be gradually brought up. Libraries in the new conditions of development and reform of the national education system must apply innovative forms and methods of organizing patriotic education, using their full potential. Specialists from other spheres, not only teachers, should be actively involved in the work of libraries on historical, patriotic and spiritual education.

Key words: patriotism, patriotic education, library system.

Библиотеки, как и школы, учитывают возрастные особенности ребенка. В работе с младшими школьниками работники библиотеки больше делают уклон на эмоциональное воздействие, но уже в старшей школе работа направлена на формирование определенных качеств личности, систему ценностей.

Главное - это помочь подрастающему человеку всеми доступными в библиотеке средствами сформироваться как личности, сформировать основные понятия о родине и патриотизме [8]. Тут самое время назвать основные направления работы библиотек в вопросах воспитания подрастающего поколения:

- духовно-нравственное воспитание. Создает основную базу для формирования личностных ценностей, идеалов и ориентиров;

- историко-патриотическое воспитание. Главная цель этой деятельности знакомство детей с историей России, формирование уважительного отношения к прошлому и павшим в боях за Родину;

- краеведение. Здесь множество направлений, от исторического до географического краеведения. Задача - это формирование у детей чувства любви к родному краю, а также бережного отношения к родной природе, познание исторически корней. Воспитание чувства сопричастности, гордости за деяния предков и современников;

- гражданско-патриотическое воспитание ориентировано на формирование правовой культуры, принятие норм и правил поведения в обществе, уважительное отношение к ближнему, свое семье и родным.

Библиотеки неразрывно связаны с духовно-нравственным, эстетическим воспитанием, в эту канву должны органично включатся вопросы патриотического воспитания, и роль книги в этом просто неоценима [2]. 
Книга становится средством патриотического воспитания на всех этапах становления личности. В детском саду и младшей школе необходимо использовать красочно оформленные книги, в том числе и русские сказки, учащие добру, любви к родной земле, готовности стать на ее защиту.

В средней и старшей школе использовать литературу, повествующую о героическом подвиге народа в годы Великой Отечественной войны 1941-1945 гг., о стойкости российских военных в горячих точках планеты. Борьбы с мировых терроризмом.

Библиотека - это не только хранилище книг и читальный зал, а и особое духовное место, где можно провести всевозможные мероприятия. В рамках патриотического воспитания можно провести литературно-музыкальный вечер, посвященный основным историческим вехам нашей истории [5].

Читательский зал, легко преобразуется в зрительный, тогда появляется возможность провести, к примеру, конкурс патриотической песни, провести круглый стол с приглашением людей [3]. Так сказать героических профессий, спасателей. Военных и так далее.

Действенным средством выступает и изобразительное искусство. Библиотека идеально подходит для конкурса рисунков на военнопатриотическую тему, организовать художественную выставку на военную тему, подкрепив ее литературными произведениями [7].

Какие бы формы и методы не использовала библиотека, основным средством патриотического воспитания подрастающего поколения в подобных учреждениях остается выставка.

В наше время всеобщей компьютеризации и интернета, библиотеки остаются главным звеном в формировании и воспитании личности. Ведь, несмотря на новые технические возможности, книга остается главным источником знаний, а умение читать основным качеством образованного человека. В этой связи, патриотическое воспитание детей и молодежи в библиотеках становится важным элементом организации учебно-воспитательного процесса [4].

Основываясь на предыдущем опыты, работники российских библиотек четко осознали, что патриотизму нельзя научить, ему надо постепенно воспитывать. Библиотеки в новых условиях развития и реформирования системы отечественного образования должны применять инновационные формы и методы организации патриотического воспитания, используя весь свой потенциал. К работе библиотек по 
историко-патриотическому и духовному воспитанию должны активно привлекаться специалисты других сфер, не только педагоги [1].

Библиотеки неразрывно связаны с духовно-нравственным, эстетическим воспитанием, в эту канву должны органично включатся вопросы патриотического воспитания, и роль книги в этом просто неоценима.

Книга становится средством патриотического воспитания на всех этапах становления личности. В детском саду и младшей школе необходимо использовать красочно оформленные книги, в том числе и русские сказки, учащие добру, любви к родной земле, готовности стать на ее защиту.

В средней и старшей школе использовать литературу, повествующую о героическом подвиге народа в годы Великой Отечественной войны 19411945 гг., о стойкости российских военных в горячих точках планеты. Борьбы с мировых терроризмом.

Библиотека, это не только хранилище книг и читальный зал, а и особое духовное место, где можно провести всевозможные мероприятия. В рамках патриотического воспитания можно провести литературномузыкальный вечер, посвященный основным историческим вехам нашей истории.

Читательский зал, легко преобразуется в зрительный, тогда появляется возможность провести, к примеру, конкурс патриотической песни, провести круглый стол с приглашением людей. Так сказать героических профессий, спасателей. Военных и так далее.

Действенным средством выступает и изобразительное искусство. Библиотека идеально подходит для конкурса рисунков на военнопатриотическую тему, организовать художественную выставку на военную тему, подкрепив ее литературными произведениями [10].

Какие бы формы и методы не использовала библиотека, основным средством патриотического воспитания подрастающего поколения в подобных учреждениях остается выставка.

Какое бы мероприятие не проводилось, оно всегда сопровождается литературной выставкой. Книги всегда подбираются по тематике мероприятия, а само мероприятие должно побудить ребенка прочитать представленные по теме книги.

Сегодня технические средства позволяют использовать интерактивные средства при организации вставки, а также провести виртуальный экскурс по страницам литературных произведений [6]. 
Только комплексный подход, с использованием различных форм и методов, поможет сформировать у ребенка целостные качества высокоразвитой личности, чувство любви к Родине и гордости за свой народ. Библиотеки способны, а главное формируют у подрастающего поколения на данном этапе развития общества стойкую гражданскую позицию, способствуют восприятию детьми национальных ценностей и чувства патриотизма [9].

Библиотеки обладают огромным потенциалом в вопросах организации и реализации патриотического воспитания, и при должном финансировании со стороны государства, своевременном обновлении материальной базы, способны выполнить свою основную функцию.

\section{Литература}

1. Гогиберидзе, Г. М. Исследование динамики читательской культуры современной российской молодежи / Г. М. Гогиберидзе // Вестник Московского городского педагогического университета. Серия : Философские науки. - 2019. - № 3. - С. 64-72.

2. Головачев, В. С. Всероссийская акция «Рисуем Победу» : методические рекомендации / В. С. Головачев, А. И. Аршинова. - Чебоксары : Издательский дом «Плакат», 2019. - 60 с.

3. Головачев, В. С. Нравственно-патриотическое воспитание детей младшего возраста в условиях межведомственного взаимодействия (из опыта проведения Всероссийской акции «Рисуем Победу») / В. С. Головачев // Сборник трудов участников Всероссийской научно-практической конференции «Рисуем Победу-2019». - 2019. - С. 26-32.

4. Крылова, Н. Б. Гражданское образование как новое и хорошо забытое старое / Н. Б. Крылова // Народное образование. - 2016. № 1. - C.48-55.

5. Лесняк, В. И. Патриотическое воспитание: проблемы и пути их решения / В. И. Лесняк // Педагогика. - 2018. - № 5. - С. 110-114.

6. Михайлюкова, А. В. Современные технологии гражданскопатриотического воспитания (на примере г. Ставрополя) / А. В. Михайлюкова // Актуальные проблемы отечественной и зарубежной истории в работах молодых исследователей: сборник материалов. Ставрополь : Издательство СКФУ, 2014. - Выпуск 5. - С. 55-59.

7. Педагогика и психология в инновационных процессах современного образования: монография. - Ставрополь : Издательство СГУ, 2017. - 496 с. 
8. Рябов, В. В. Воспитание гражданина / В. В. Рябов // Вестник Московского городского педагогического университета. - 2018. № 4. - С. 112-116.

9. Следзевский, И. В. Гражданско-патриотическое воспитание детей и молодежи: проблемы и стратегия / И. В. Следзевский // Преподавание истории и обществознания в школе. - 2017. - № 7. - С. 9-15.

10. Третьяков, А. Л. Гражданско-патриотическое и этико-правовое просвещение обучающихся в современной школьной библиотеке: некоторые подходы к теоретическому осмыслению проблемы / А. Л. Третьяков // Вестник Саратовского областного института развития образования. - 2017. - № 1. - С. 38-43. 
Кожанов И. В.,

проректор по научной и инновационной работе Чувашского государственного педагогического университета им. И. Я. Яковлева, доктор педагогических наук, доцент

Головачев В. С., художественный руководитель Всероссийской детско-юношеской акции «Рисуем Победу», доцент кафедры гуманитарных дисциплин Чувашского государственного педагогического университета им. И. Я. Яковлева

\section{НРАВСТВЕННО-ЭСТЕТИЧЕСКОЕ ВОСПИТАНИЕ ДОШКОЛЬНИКОВ В ФОРМАТЕ СЕТЕВОГО ОНЛАЙН-ПРОЕКТА}

Аннотация. В статье рассматриваются практические аспекты организации нравственно-эстетического воспитания дошкольников в условиях дистанционного взаимодействия учреждений дошкольного образования и культуре на базе совместного онлайн-проекта - Всероссийской акции «Рисуем Победу». Приводятся статистические данные реализации проекта, методические решения, делаются выводы об эффективности представленной модели межведомственного взаимодействия и возможности ее дальнейшего масштабирования в системе дошкольного образования и образования в сфере культуры.

Ключевые слова: нравственность, воспитание, нравственноэстетическое воспитание, дета, дошкольники, онлайн-платформа, проект, проектный подход.

Kozhanov I. V.,

Vice-rector for Scientific and innovative Work of the I. Ya. Yakovlev Chuvash State Pedagogical University, Doctor of Pedagogical Sciences, Associate Professor

Golovachev V. S., Artistic Director All-Russian children's and youth action "Draw a Victory", Department of Humanities of the I. Ya. Yakovlev Chuvash State Pedagogical University

\section{MORAL AND AESTHETIC EDUCATION OF PRESCHOOL CHILDREN IN THE FORMAT OF AN ONLINE NETWORK PROJECT}

Abstract. The article discusses the practical aspects of the organization of moral and aesthetic education of preschoolers in the conditions of remote 
interaction of preschool education institutions and culture on the basis of a joint online project-the All - Russian campaign "Draw a Victory". The statistical data of the project implementation, methodological solutions are presented, conclusions are drawn about the effectiveness of the presented model of interdepartmental interaction and the possibility of its further scaling in the preschool education system

Keywords: morality, education, moral and aesthetic education, children, preschoolers, online platform, project, project approach.

В современной отечественной системе дошкольного образования большое внимание уделяется нравственно-эстетическому воспитанию дошкольников. Именно в дошкольном возрасте начинается формирование основополагающих личностных качеств. Трудно переоценить значение воспитательно-просветительского сегмента, знакомящего дошкольника с основами искусства, приемами творчества, важнейшими нравственными и эстетическими идеалами [9].

Обращение к славным страницам Отечественной истории, подвигу предков, защитивших свободу и независимость страны - важный этап приобщения ребенка к идеалам нравственности и патриотизма [1, с. 99]. Знакомство с событиями, персоналиями и образами Великой Отечественной войны начинается для многих детей в дошкольном учреждении. Рассказать о войне, как о страшной беде, уносящей человеческие жизни, уничтожающей красоту природы, искусства и культуры - сложная и важная задача воспитателя, для эффективного решения которой необходимо задействовать широкий арсенал педагогических средств и приемов [6, с. 38].

Знакомство с военно-патриотической темой через творческое осмысление - один из действенных и запоминающихся для детского сознания приемов. Узнать факты о войне, познакомиться с произведениями изобразительного, вокального, музыкального и киноискусства на военную тему, а затем, на основе увиденного, услышанного и осознанного создать собственную творческую работу - сложный ступенчатый процесс, требующий от воспитателя значительной подготовки и наличия должной материально-технической базы [5].

Эпидемия новой коронавирусной инфекции стала серьезным вызовом системе образования, в том числе - ее дошкольной ступени. 
Многие классические приемы и формы работы с дошкольной аудитории стали временно недоступными в связи с введенными эпидемическими ограничениями.

Вместе с тем, возросла актуальность и востребованность удаленных форм работы, в том числе, партнерских онлайн-проектов. Реализация подобных проектов, в которых дошкольное учреждение становится партнером учреждений другой ведомственной принадлежности в безопасном онлайн-формате значительно расширяет возможности создаваемого проекта.

Ярким примером подобного взаимодействия является реализация детско-юношеской акции «Рисуем Победу» [2]. В 2020-2021 гг. проведение Акции было полностью переведено в онлайн-формат. Для успешной координации работы коллективов учреждений-соорганизаторов, удобства и безопасности участников была разработана онлайн-платформа «Рисуем Победу» [7], которая включила в себя информационно-просветительский модуль, онлайн-механизм загрузки творческих работ, получения электронных сертификатов участия, счетчики учета статистики.

Акция проводится с целью формирования и развития у детей и молодежи чувства патриотизма, национального самосознания и сопричастности к беспримерному подвигу советского народа в Великой Отечественной войне по средствам вовлечения в живой диалог поколений и создания художественных образов, на основе услышанного и осознанного исторического материала.

Проект реализуется среди детей (обучающихся дошкольных отделений образовательных комплексов, учащихся общеобразовательных и специализированных школ, учреждений дополнительного образования детей, читателей детских библиотек); молодежи (воспитанников подростково-молодежных центров и клубов, членов молодежных общественных организаций, индивидуальных участников).

Сетевой формат реализации проекта позволил максимально задействовать потенциал учреждений дошкольного образования и культуры: сотрудниками детских библиотек-участников проекта были подготовлены интерактивные презентации, информационно-справочные модули, списки рекомендуемой литературы [3, с. 16-17]. Сотрудники учреждений дошкольного образования приняли активное участие в разработке положения, адаптации творческих заданий под специфику возрастных групп участников. 
К участию в акции принимаются детские художественные работы (живопись, графика, декоративно-прикладное искусство, коллаж), краткие тексты (эссе), посвященные беспримерному подвигу советского народа в Великой Отечественной войне 1941-1945 гг.

К основным задачам акции можно отнести:

- гражданско-патриотическая: воздать дань памяти героям, осознать и осмыслить значение подвига советского народа в Великой Отечественной войне;

- воспитательная: формирование положительных личностных качеств у детей и молодежи по средствам знакомства с героями, фактами и событиями Великой Отечественной войны;

- образовательная: формирование у детей и молодежи четкого и правдивого представления о событиях и итогах Великой Отечественной войны;

- культурно-просветительная: широкая популяризация по средствам детского творчества значения праздника - Дня Победы;

- социальная: мотивация к диалогу поколений внутри семьи и уважительному отношению к представителям старшего поколения участникам и свидетелям Великой Отечественной войны;

- коммуникативная: объединение молодежи и молодежных организаций посредствам совместной работы над реализацией проекта;

- художественно-эстетическая: вовлечение детей и молодежи в творческий процесс создания художественного и литературного произведения на заданную военно-патриотическую тему;

- организационно-методическая: помощь учреждениям дошкольного образования, общеобразовательным и специализированным школам в организации и проведении памятных мероприятий, посвященных Великой Отечественной войне.

Количественные показатели проведения Акции также подтверждают высокую вовлеченность регионов. Заявки на участие в творческой акции в 2021 г. подали 531779 юных авторов из России, Белоруссии, Казахстана, Армении, Таджикистана, Киргизии из более, чем 11,5 тысяч населенных пунктов. Москва традиционно стала лидером по охвату участников: на официальный сайт акции было загружено 18337 рисунков.

Общая статистика по охвату участников представлена в таблице 1: 
Таблица 1. Статистика по охвату участников акции «Рисуем Победу» в 2021 г.

\begin{tabular}{|c|c|}
\hline \multicolumn{2}{|c|}{$\begin{array}{c}\text { Всего участников акции - } 531779 \text { чел. } \\
\text { Всего населенных пунктов - } 11586\end{array}$} \\
\hline \multicolumn{2}{|c|}{ Зарубежные участники - 1907 человек: } \\
\hline Республика Беларусь & 1416 чел. \\
\hline Республика Казахстан & 218 чел. \\
\hline Республика Армения & 112 чел. \\
\hline Кыргызская Республика & 105 чел. \\
\hline Республика Таджикистан & 56 чел. \\
\hline \multicolumn{2}{|c|}{ Российская Федерация - 529872 человека } \\
\hline \multicolumn{2}{|c|}{$\begin{array}{l}\text { Федеральные округа Российской Федерации, } \\
\text { населенные пункты-лидеры: }\end{array}$} \\
\hline Центральный ФО - 157421 чел. & $\begin{array}{l}\text { г. Москва - } 18337 \\
\text { Московская область } 12121 \text { чел. } \\
\text { Брянск - } 4179 \text { чел. } \\
\text { Орел - } 3477 \text { чел. } \\
\text { Кострома - } 1598 \text { чел. } \\
\text { Тамбов - } 1998 \text { чел. } \\
\text { Белгород - } 1981 \text { чел. } \\
\text { Воронеж - } 1869 \text { чел. } \\
\text { Клинцы - } 1188 \text { чел. }\end{array}$ \\
\hline Приволжский ФО: 56314 чел. & $\begin{array}{l}\text { Ульяновск - } 7127 \text { чел. } \\
\text { Нижний Новгород - } 6487 \text { чел. } \\
\text { Пермь - } 4471 \text { чел. } \\
\text { Ижевск - } 2211 \text { чел. } \\
\text { Башкортостан - } 1895 \\
\text { Оренбург - } 1473 \text { чел. } \\
\text { Саратов - } 1419 \text { чел. } \\
\text { Балаково - } 1085 \text { чел. } \\
\text { Чебоксары - 502 чел. }\end{array}$ \\
\hline Уральский ФО: 91632 чел. & $\begin{array}{l}\text { Челябинск - } 14526 \text { чел. } \\
\text { Екатеринбург - } 3410 \text { чел. } \\
\text { Копейск - } 1789 \text { чел. } \\
\text { Троицк - } 1350 \text { чел. } \\
\text { Тюмень - } 980 \text { чел. } \\
\end{array}$ \\
\hline Южный ФО: 32182 чел. & Краснодар - 5233 чел. \\
\hline
\end{tabular}




\begin{tabular}{|c|c|}
\hline & $\begin{array}{l}\text { Анапа - } 2209 \text { чел. } \\
\text { ростов-на-дону - } 1857 \text { чел. } \\
\text { Сочи - } 971 \text { чел. } \\
\text { Севастополь }-412 \text { чел. } \\
\text { Астрахань - } 256 \text { чел. }\end{array}$ \\
\hline Северо-Западный ФО: 52535 чел. & $\begin{array}{l}\text { Санкт-Петербург - } 9424 \text { чел. } \\
\text { Петрозаводск - } 7125 \text { чел. } \\
\text { Вологда - } 1275 \text { чел. } \\
\text { Мурманск - } 970 \text { чел. }\end{array}$ \\
\hline Сибирский ФО: 53015 чел. & $\begin{array}{l}\text { Новосибирск - } 7131 \text { чел. } \\
\text { Горно-Алтайск - } 6450 \text { чел. } \\
\text { Омск - } 3210 \text { чел. } \\
\text { Барнаул - } 1402 \text { чел. }\end{array}$ \\
\hline Северо-Кавказский ФО: 81729 чел. & $\begin{array}{l}\text { Грозный - } 4018 \text { чел. } \\
\text { Ставрополь - } 1936 \text { чел. } \\
\text { Гудермес - } 1337 \text { чел. } \\
\text { Кисловодск - } 831 \text { чел. } \\
\text { Махачкала - } 802 \text { чел. }\end{array}$ \\
\hline Дальневосточный ФО: 5062 чел. & $\begin{array}{l}\text { Благовещенск - } 1421 \text { чел. } \\
\text { Белогорск - } 871 \text { чел. } \\
\text { Свободный - } 413 \text { чел. }\end{array}$ \\
\hline
\end{tabular}

Несмотря на отсутствие очных мероприятий в рамках заявленной акции, онлайн-формат показал хорошие количественные и качественные результаты реализации проекта. Итоговое выборочное анкетирование представителей площадок реализации проекта, показало, что воспитатели и руководители дошкольных учреждений высоко оценили доступность и удобный формат использование информационно-справочных, методических и демонстрационных материалов, размещенных на сайте. Отметили высокую степень мотивированности воспитателей, родителей и самих детей, связанную с публичным показом для широкой онлайнаудитории результатов творческой работы, широким освещением в СМИ, получением памятных дипломов и сертификатов.

Подводя итоги реализации этапа реализации акции «Рисуем Победу» в онлайн-формате можно отметить эффективность использования подобного сетевого партнерского взаимодействия и целесообразность его внедрения в процесс нравственно-эстетического воспитания детей дошкольного возраста. 


\section{Литература}

1. Гогиберидзе, Г. М. Духовно-нравственное воспитание как значимый ресурс обеспечения социальной безопасности / Г. М. Гогиберидзе // Актуальные проблемы социально-педагогической деятельности в контексте социальной безопасности в современном российском обществе. - Коломна, 2017. - С. 98-105.

2. Головачев, В. С. Всероссийская акция «Рисуем Победу» : методические рекомендации / В. С. Головачев, А. И. Аршинова. - Чебоксары : Плакат, 2019. - 60 с.

3. Демидов, А. А. Сетевая модель центров этико-правового образования и гражданско-патриотического воспитания и центров медиаобразования на базе школьных библиотек: необходимость создания, возможности и реальные перспективы / А. А. Демидов, А. Л. Третьяков // Медиаобразование. - 2016 - № 3. - С. 16-22.

4. Осокина, Т. В. Организация проектной деятельности в учебновоспитательном процессе школы / Т. В. Осокина, Е. Г. Хрисанова, В. В. Петрова // XXIX Ершовские чтения. Педагогическое образование: вызовы времени. - Ишим, 2019. - С. 59-61.

5. Третьяков, А. Л. Формирование межведомственной и межсекторной модели развития гражданского, патриотического и этико-правового образования и воспитания молодежи в формате социального проекта «Центр гражданской, этико-правовой и иной социально значимой информации памяти профессора Н. И. Элиасберг» / А. Л. Третьяков, А. А. Демидов // От науки к бизнесу «Трансфер технологий - новое измерение». - Санкт-Петербург, 2015. - С. 136-139.

6. Третьяков, А. Л. Гражданско-патриотическое и этико-правовое просвещение обучающихся в современной школьной библиотеке: некоторые подходы к теоретическому осмыслению проблемы / А. Л. Третьяков // Вестник Саратовского областного института развития образования. - 2017. - № 1. - С. 38-43.

7. Сайт акции «Рисуем Победу» [Электронный ресурс]. - URL : http://risuem-pobedu.ru/ (дата обращения: 02.07.2021).

8. Скрынник, М. А. Воспитание нового патриота / М. А. Скрынник // Нравственно-эстетическое и гражданско-патриотическое воспитание в государственных учреждениях образования и культуры. - Чебоксары, 2019. - С. $82-86$. 
Комарова И. И.,

кандидат исторических наук, доцент кафедры дошкольного образования Московского государственного областного университета, проректор по научной работе Международной педагогической академии дошкольного образования

Комарова Т. $\boldsymbol{C}$. доктор педагогических наук, профессор, заслуженный деятель науки Российской Федерации, профессор кафедры эстетического воспитания детей дошкольного возраста Московского педагогического государственного университета, профессор кафедры дошкольного образования Московского государственного областного университета

Третьяков А. Л. доцент кафедры дошкольного образования Московского государственного областного университета, старший преподаватель кафедры социальной психологии Московского психолого-социального университета

\section{ХУДОЖЕСТВЕННО-ЭСТЕТИЧЕСКОЕ ВОСПИТАНИЕ В СОВРЕМЕННОМ ДОШКОЛЬНОМ ДЕТСТВЕ}

Аннотация. В статье представлена специфика художественно-эстетического воспитания в современном дошкольном образовании. Определено, что главная цель изобразительной деятельности в детском саду - духовно обогатить ребенка, научить проникновению в эстетическую сущность окружающего, природы и произведений искусства, на базе которых строится продуктивная деятельность.

Ключевые слова: художественно-эстетическое воспитание, детский сад, дошкольное детство, специфика, условия.

Komarova I.I.,

Candidate of Historical Sciences, Associate Professor of the Department of Preschool Education Moscow Region State University, Vice-rector for scientific work International Pedagogical Academy of Preschool Education

Komarova T.S. Doctor of Pedagogy, Professor, Honored Scientist of the Russian Federation, Professor of the Department of Aesthetic Education of Preschool Children Moscow State Pedagogical University, Professor of the Department of Preschool Education Moscow Region State University 
Tretyakov A. L.,

Associate Professor at the Department of Preschool Education Moscow Region State University, Senior Lecturer at the Department of Social Psychology Moscow Psychological and Social University

\section{ARTISTIC AND AESTHETIC EDUCATION IN MODERN PRESCHOOL CHILDHOOD}

Abstract. The article presents the specificity of artistic and aesthetic education in modern preschool education. It has been determined that the main goal of visual activity in kindergarten is to spiritually enrich the child, to teach penetration into the aesthetic essence of the environment, nature and works of art, on the basis of which productive activity is built.

Key words: artistic and aesthetic education, kindergarten, preschool childhood, specificity, conditions.

Детство - это период усиленного развития, изменения и обучения.

Период дошкольного и младшего школьного детства является едва ли не самым решающим с точки зрения эстетического воспитания и формирования нравственно-эстетического отношения к жизни. На дошкольном этапе взросления происходит наиболее интенсивное формирование отношений к миру, которые постепенно переходят в свойства личности, отличительные особенности которого отражены в работах отечественных ученых [1-8].

Большое значение для изучения психологических особенностей старших дошкольников имели работы таких исследователей, как Л. А. Венгер, А. В. Запорожец, 3. М. Леонтьева, А. Н. Поддяков, Д. Б. Эльконин и др. Эти работы отражали следующее: особенности развития мотивационной и психической сфер, а также индивидуальных познавательных процессов детей; развитие особенностей общения и способов социального взаимодействия; специфику изобразительной, трудовой и других видов деятельности детей, механизмы формирования у дошкольников элементарной учебной деятельности, а также готовность к началу школьного обучения.

Старший дошкольный возраст является периодом интенсивного формирования личности ребенка во всех сферах: повышения интеллекта; выработки нравственных черт; проявления характера, силы воли; умения управлять эмоциями; физической подготовленности. 
Именно в это время проявляются совершенно новые, индивидуальные качества, растут потребности детей в получении все новых знаний, навыков и умений. Важные особенности в деятельности старших дошкольников - это целенаправленное развитие через творчество. Творческая самостоятельная деятельность детей проявляется в следующих направлениях: всевозможных играх; театральных, кукольных и других представлениях, мини-спектаклях; исполнении танцевальных композиций; художественно-изобразительной деятельности; разнообразном ручном труде; чтении стихотворений, разучивании песен и прочих видах словесного творчества.

Bсе перечисленное выше, является фактором успешного художественно-эстетического воспитания детей старшего дошкольного возраста.

Для правильной организации системы работы по художественноэстетическому воспитанию, необходимо описать ее примерное содержание, определить конкретные требования, соответствующие общим целям воспитания, к дошкольникам каждой возрастной группы. Это позволит избежать односторонности, спонтанности, случайности в выборе методов и средств эстетического воспитания, поможет спланировать работу, расположить материал в нужной последовательности, увидеть его конечные цели.

В нашей работе мы рассматриваем изобразительную деятельность, как особенно сильное и незаменимое средство художественно - эстетического воспитания старших дошкольников. Изобразительная деятельность - это образное познание действительности и продуктивный вид деятельности ребенка. Эта деятельность включает взаимосвязь трех составляющих: рисование, представляющее собой синтетическую деятельность, способствует проявлению психического развития, использованию опыта, приобретенного в различных видах деятельности, а также усвоению различных элементов социального опыта и человеческой культуры; лепки, отображающей предметы окружающей действительности в виде элементарной скульптуры; аппликации - плоскостной контурно-силуэтной трактовки образа, способа создания художественных изображений, узоров путем набивания, наклеивания на ткань, бумагу и т. д. разнообразных по признакам готовых форм.

Известный ученый в области эстетического воспитания Т. С. Комарова рассматривала понятие «изобразительная деятельность» очень широко по своему содержанию, поскольку оно включает в себя различные виды изобразительного искусства: графику, живопись, скульптуру, 
архитектуру и др. Рисунок - общая основа, фундамент для изобразительного искусства. На нем строятся различные виды изобразительной деятельности. По этой причине способности к рисованию с дошкольного возраста являются наиболее значимыми и необходимыми. Рисование, лепка, аппликация и конструирование - виды изобразительной деятельности. Каждый вид изобразительного искусства помогает отобразить впечатления ребенка, которые он получает из окружающего мира. Задачи изобразительной деятельности конкретизируются в зависимости от особенностей каждого вида, своеобразия материала, оригинальности, а также методов и приемов работы с ним.

Важным фактором художественно-эстетического воспитания старших дошкольников является образовательная программа. На сегодняшний день существует целый ряд основных примерных и парциальных программ. Выбор программ является ответственным и сложным шагом. В образовательных программах ДОО основные задачи художественноэстетического воспитания решаются по-разному. Образовательные программы дошкольного образования «От рождения до школы», «Детство», «Истоки», «Радуга» содержат раздел по художественно - эстетическому воспитанию. Но каждая программа имеет свою концепцию построения данного процесса.

Художественно-эстетическое воспитание в программе «Детство» (В. И. Логинова, Т. И. Бабаева, Н. А. Ноткина и др.) реализуется в процессе ознакомления с природой, разными видами искусства и художественно-эстетической деятельности.

В программе «От рождения до школы» (под редакцией Н. Е. Вераксы, Т. С. Комаровой, М. А. Васильевой) особое место уделяется художественно-эстетическому воспитанию. Там прописаны две области, составляющие единое целое «Художественное творчество» и «Музыка».

Программа «Радуга» (авторский коллектив лаборатории Института общего образования МО РФ под руководством профессора Т. Н. Дороновой) нацелена на развитие изобразительной деятельности на основе знакомства с народным декоративным искусством.

Программа «Истоки» (составлена авторским коллективом центра «Дошкольное детство» им. А. В. Запорожца под руководством Л. А. Парамоновой) ориентирована на приобщение детей к культуре и быту родного края.

Вместе с тем без внимания нельзя оставлять парциальные про- 
граммы по художественно-эстетическому воспитанию: Программа эстетического воспитания детей двух-семи лет «Красота. Радость. Творчество» (авторы Т. С. Комарова, А. В. Антонова, М. Б. Зацепина), программа «Цветные ладошки» (И. А Лыкова), программа «Гармония развития〉 (Д. И. Воробьева).

Каждая из указанных выше программ на сегодняшний день является наиболее разработанной для практического решения проблемы художественно-эстетического воспитания. В каждой программе, помимо того, что имеется своя концептуальная позиция, разработанная структура и технология, которая позволяют практикам внедрять ее с учетом реальных условий. Программы дошкольного образования содействует становлению всесторонне развитой личности ребенка, развитию его творческих способностей, навыков, знаний и умений в области художественного - эстетического воспитания.

Таким образом, главная цель изобразительной деятельности в детском саду - духовно обогатить ребенка, научить проникновению в эстетическую сущность окружающего, природы и произведений искусства, на базе которых строится продуктивная деятельность.

В ДОО в аспекте художественно-эстетического воспитания выявлены и необходимы в применении разнообразные методы, формы для формирования творческой личности ребенка. Средства, приемы и методы художественно - эстетического воспитания детей дошкольного возраста изучались большим коллективом ученых, среди них были Н. А. Ветлугина, Е. А. Флерина, Р. М. Чумичева, Е. М. Торшилова и др. Эти авторы рассматривали художественно - эстетическое развитие ребенка как основной компонент общего развития и образования. Н. А. Ветлугина приложила большой труд в разработке теоретических основ эстетического воспитания детей дошкольного возраста. Воспитывая ребенка в эстетическом направлении, мы развиваем его эстетическое восприятие, чувства, художественно-эстетический вкус, художественно-творческие способности.

Суть методов художественно-эстетического воспитания заключается в совместной взаимосвязанной работе воспитателя и ребенка, направленной на развитие эстетических идей, эстетических чувств и художественной деятельности, которая предполагает становление основ эстетического вкуса и развитие способностей к творчеству. Положительный эффект работы по художественно-эстетическому воспита- 
нию во многом определяется тем, как педагог учитывает индивидуальные особенности, интересы, потребности дошкольника, а также уровень его общего развития.

Существует множество различных групп - методов художественноэстетического воспитания. В нашей работе будет представлена следующая классификация выдающего деятеля в области художественно-эстетического воспитания Н. А. Ветлугиной:

- метод убеждения. Этот метод направлен на развитие эстетического восприятия, оценки, начальных проявлений вкуса. Метод убеждения в рамках эстетического воспитания может быть использован только тогда, когда воспринимаемое явление отражает красоту;

- метод приучения включается в себя упражнения практической направленности. Они предназначены для преобразования окружающей среды, а также развития навыков культуры поведения. Суть метода приучения, упражнений заключается в том, что ребенку важно научиться слушать, смотреть, оценивать прекрасное, что влечет за собой активность действий;

- метод проблемных ситуаций, побуждающий к творческим и практическим действиям. При использовании этого метода взрослый предлагает детям придумать историю, лепить из пластилина, глины, вырезать из цветной бумаги детали, а потом создавать композицию, а также рисовать по собственному замыслу и т. д.;

- метод побуждения к сопереживанию, сочувствию, эмоциональноположительному отклику на красивое и негативное отношение к безобразному в мире. Этот метод эффективен, когда взрослые используют произведения искусства с высоким художественным мастерством, а дошкольники слушают музыку, сказки, стихи, не только точно воспроизводят текст, но и выполняют его эмоционально и образно. Только в этом случае можно добиться воспитательного эффекта.

Отбирая методы и приемы, мы учитываем цель и содержание занятий, программное обеспечение в системной работе по художественноэстетическому воспитанию, возрастной контингент детей. Очень важно активизировать умственную активность детей и их самостоятельность. Мыслительная деятельность прослеживается, прежде всего, по мере сложности выдвигаемых задач, последовательности их постановки, использования заданий проблемного характера, и, несомненно, вовлечения в нее детского опыта.

В сочетание с традиционными методами обучения, мы рассмотрели, 
в том числе и интерактивные формы организации деятельности: работу в группах и в парах; игровые и занимательные упражнения; ИКТ-технологии; игровые-педагогические ситуации, например, развивающая ситуация «Интервью с художником»; метод нестандартных творческих ситуаций, пробуждающий интерес к художественной деятельности; фотоэкскурсии; виртуальный музей.

В процессе художественно-эстетического воспитания указанные методы приобретают специфику, которая применяется и моделируется в различных видах деятельности детей. В дошкольной образовательной организации работа по художественно - эстетическому воспитанию проводится в течение всего дня, начиная с момента поступления детей в дошкольную образовательную организацию.

Таким образом, мы убеждаемся, что только комплекс различных средств, методов и форм может обеспечить полноценное художественно - эстетическое воспитание ребенка в детском саду. Главная забота о полноценном образовании детей осуществляется в стенах детского сада. Возможность воздействия дошкольной организации по художественно - эстетическому воспитанию детей гораздо шире, чем, например, в семье. Детский сад имеет более разнообразную структуру проведения занятий, больше средств воздействия на ребенка, наличие высококвалифицированных специалистов, предметно-развивающую среду, и конечно многообразие форм воспитательной работы. Формы организации воспитательного процесса, в рамках которых осуществляется образовательный процесс; система целесообразной организации коллективной и индивидуальной деятельности воспитанников, складывающейся в зависимости от направления воспитательной работы количества участников (групповая, массовая, индивидуальная).

В дошкольных образовательных организациях используются следующие формы работы по художественно-эстетическому воспитанию с детьми:

- беседы - позволяют детям обогатиться понятиями о сущности и особенностях красоты в искусстве, творчестве, поведении людей. Во время беседы необходимо систематизировать накопленные детьми знания, обмениваться мнениями и детскими впечатлениями. Успех правильно выстроенного разговора определяется его эмоциональным интересом. Во время беседы необходимо использовать наглядность, рождающая яркие впечатления. Важным моментов в беседе - являются 
ясно сформулированные вопросы, которые вызвали бы познавательный интерес у детей, стимулировали бы рефлексию и конкретизацию их оценок и суждений;

- интеграция непосредственной образовательной деятельности с другими образовательными областями (развитие речи, изобразительное искусство, музыка, конструирование, моделирование и др.);

- совместная деятельность воспитателя и детей в режиме дня. Основная модель организации образовательного процесса детей дошкольного возраста. Отличается наличием партнерской (равноправной) позиции взрослого и партнерской формой организации (возможность свободного размещения, перемещения и общения детей в процессе образовательной деятельности). В режимных моментах больше свободного времени, чтобы уделить внимание рассматриванию персонажей, иллюстраций, репродукций различных картин, что позволит в дальнейшем повысить интерес к художественно-эстетической деятельности;

- выставка детских работ (это компонент развивающей среды) позволяет демонстрировать динамику, а также контролировать результаты воспитательной работы;

- экскурсия, в природу или в музей. Как отмечают С. А. Козлова, Т. А. Куликова основной задачей, которую должен выполнить педагог, является планирование плана экскурсии с учетом законов детского восприятия, воспитательных задач. Экскурсия дает дошкольникам новые знания и опыт, а также пробуждает в них эстетические чувства. С детьми можно организовать экскурсии на природу, к памятникам архитектуры, галереи, в музеи или на выставки экспонатов искусства;

- праздники, организованные педагогами, в рамках детских концертов, конкурсов, театральных тематических и литературных постановок и вечеров, игры - развлечений, квестов, путешествий, сюрпризов, музыкальных сказок. Праздники и развлечения, как формы работы, наполняют детей новыми яркими впечатлениями в дошкольной образовательной организации, связанными с памятными датами, вызывают эмоциональную отзывчивость и интерес к разнообразным видам художественной деятельности;

- самостоятельная творческая деятельность;

- совместная работа с родителями. Основным принципом при организации работы с семьей в рамках работы по эстетическому воспитанию является: единство целей и задач художественно-эстетического развития ребенка в дошкольной образовательной организации и семье. 
Вышеизложенные формы работы составляют «каркас» образовательной среды в рамках художественно-эстетического воспитания.

Таким образом, краткий словарь по эстетике определяет эстетический вкус как - система эстетических предпочтений и ориентаций, основанная на обобщенной и творческой переработке эстетических впечатлений, способность человека отличать красивое от не красивого, прекрасное от безобразного, возвышенное от низменного, трагическое от комического. Эстетический вкус на уровне детей дошкольного возраста - это эстетическая оценка воспринятых явлений окружающего, природы и искусства. Он заключается и в понимании естественной природной красоты, глубоком осознании необходимости труда, гармоничном оформлении быта и умении красиво одеваться. Воспитание помогает сформировать правильные тенденции развития эстетического вкуса у детей.

В процессе художественного освоения мира у дошкольника прослеживается тесная связь с психическими процессами и речью. Основой эстетической оценки являются эмоциональные эталоны (радость грусть), эстетические эталоны, эмоциональный отклик (красиво-некрасиво). В старшем дошкольном возрасте эмоционально-оценочная реакция на объект имеет большое значение в развитии эстетического вкуса. Однако, дети этого возраста должны не только знать прекрасное, уметь восхищаться и оценивать, они также должны активно участвовать в создании прекрасного в трудовой деятельности, искусстве, жизни, поведении и во взаимоотношениях с другими людьми. Главное - «воспитывать, развивать у человека такие качества, потребности и способности, превращающие его в активного создателя эстетических ценностей, позволяющие не только наслаждаться красотой мира, но и преобразовывать «по законам красоты». К концу пребывания в дошкольной организации дети должны иметь возможность эстетически оценивать результаты своей деятельности, деятельность сверстников, если это возможно, приводить аргументы в пользу этой оценки, стремиться общаться в процессе художественной деятельности.

Таким образом, учитывая эстетическую сущность изобразительной деятельности и то, что именно программы по предметам художественного цикла задают цели художественно - эстетического воспитания дошкольника. Следовательно, в программах детских садов изобразительное искусство является основным средством эстетического воспитания. Обучая детей в ДОО мы, педагоги, формируем 
эмоциональную отзывчивость на выразительные средства. Первоначальные эстетические качества в произведениях искусства дети начинают не только видеть, но и осознавать.

Эстетический вкус как важнейшая категория художественно-эстетического воспитания возникает только в совокупности всех средств изобразительной деятельности и прикладного творчества.

\section{Литература}

1. Бахтина, Е. В. Межкультурный диалог в библиотеке / Е. В. Бахтина, Ю. Ф. Андреева, В. В. Орлов // Библиопанорама. - 2017. - № 1. C. 32-34.

2. Брянцева, М. В. Альтернативные формы противодействия антисоциальным проявлениям молодежных субкультур / М. В. Брянцева // Самоидентификация молодежи в социальном пространстве. - Москва, 2009. - С. 68-78.

3. Головачев, В. С. Возможности межрегионального проектного взаимодействия учреждений образования и культуры в нравственно-эстетическом воспитании дошкольников / В. С. Головачев // Вестник Чувашского государственного педагогического университета им. И. Я. Яковлева. - 2019. - № 5. - С. 143-150.

4. Головачев, В. С. Новые формы взаимодействия учреждений образований и культуры на основе культурно-образовательных интернетплатформ / В. С. Головачев // Архитектура университетского образования: построение единого пространства знаний. - Санкт-Петербург, 2020. - С. 354-361.

5. Емельяненкова, А. В. Индивидуально-психологические особенности руководителя как фактор творческого потенциала / А. В. Емельяненкова, О. В. Кобелева // Проблема творческого развития личности в XXI веке. - Ульяновск, 2004. - С. 240-241.

6. Колесникова, М. Н. Архитектура и дизайн библиотек: учеб. Пособие / М. Н. Колесникова, Е. В. Бахтина. - Санкт-Петербург : СПбГИК, 2016. - 128 с.

7. Коренева, Ю. В. Литературные экскурсии музеев как вид образовательного туризма / Ю. В. Коренева, К. С. Хосровян, О. В. Кобелева // Наука на благо человечества - 2018. - Москва, 2018. - С. 202-206.

8. Dyachenko I. L. The estimation of possibilities of product and imported raw substitution / I. L. Dyachenko, V. Sh. Khetagurova, G. A. Bryukhanova, M. N. Sosnov, M. V. Bryantseva // Biosciences Biotechnology Research Asia. - 2015. - Volume 12. - № 2. - P. 1603-1613. 
Никольская Е.В., доцент кафедры эстетического воспитания детей дошкольного возраста факультета дошкольной педагогики и психологии Московского педагогического государственного университета

\section{ДУХОВНО-НРАВСТВЕННОЕ ВОСПИТАНИЕ СТУДЕНТОВ ПЕДАГОГИЧЕСКИХ ВУЗОВ СРЕДСТВАМИ ФОЛЬКЛОРА}

Аннотация. В данной статье рассматривается проблема духовнонравственного воспитания студентов педагогических вузов, отмечается эффективность использования в решении данной проблемы фольклора.

Ключевые слова: духовно-нравственное воспитание, студенты, педагогика, народная культура, фольклор.

Nikolskaya E. V. Associate Professor of the Department of Aesthetic Education of Preschool Children, Faculty of Preschool Pedagogy and Psychology of Moscow State University

\section{SPIRITUAL AND MORAL EDUCATION OF STUDENTS OF PEDAGOGICAL UNIVERSITIES BY MEANS OF FOLKLORE}

Abstract. This article deals with the problem of spiritual and moral education of students of pedagogical universities, the effectiveness of using folklore in solving this problem is noted.

Key words: spiritual and moral education, students, pedagogy, folk culture, folklore.

Духовно-нравственные традиции любой страны являются частью культуры народа, незыблемым фундаментом общества, единства государства, формирования чувства патриотизма граждан, их нравственных идеалов. Это отмечали великие общественные деятели как прошлого, так и настоящего. В Национальной доктрине развития образования в России, утвержденной Президентом В. В Путиным в 2000 г., подчеркивается значимость «отечественного культурно-исторического и национально-культурного наследия как основы всего современного образовательного пространства нашей страны». 
В народной культуре на протяжении веков сохраняются национальные традиции, морально-этические ориентиры, эстетические и нравственные принципы воспитания подрастающего поколения.

Культурные традиции России уходят своими корнями в славное историческое прошлое, где зарождался язык; народные обряды, обычаи, семейные и общественные взаимоотношения, которые отложились в нашей генетической памяти. Важнейшая задача государства, современного образования на всех его уровнях - это духовно-нравственное воспитание подрастающего поколения. Понимание нашим обществом уникальных культурных, морально-нравственных и духовных ценностей народа - важнейшее условие в воспитании у молодежи патриотизма, привития чувства гордости за их неповторимость и уникальность в палитре многоликой мировой культуры.

На протяжении всего культурного развития русского этноса фольклор являлся средством патриотического, нравственного, духовного и эстетического воспитания. На протяжении тысячелетий песенное наследие многих поколений русского народа использовалось и для адаптации ребенка в социуме, и в качестве развивающей системы, являлось объектом изучения, источником музыкального материала для творчества композиторов.

Фольклор и сегодня проникает во все сферы жизни человека: в исполнительские формы, в композиторское творчество, в образование.

Интерес к фольклору, как к источнику воспитания и образования подрастающего поколения возник еще в XVII-XVIII вв. Труды историка В. Н. Татищева, собирательская и исследовательская деятельность А. Н. Афанасьева, А. Ф. Гильфердинга, В. И. Даля, П. В. Кириевского, М. В. Ломоносова, П. Н. Рыбникова, Л. Н. Садовникова, Б. М. и Ю. М. Соколовых, П. В. Шейна и др. позволила систематизировать и классифицировать фольклорное наследие, разработать принципы создания дисциплин по изучению фольклора для средних высших учебных заведений.

Выдающиеся просветители XIX-XX вв., композиторы М. А. Балакирев, Ц. А. Кюи, А. Г. Рубинштейн, искусствоведы В. Ф. Одоевский, А. Н. Серов, Б. Асафьев, отчасти Г. А. Ларош внесли свою лепту в создание и совершенствование будущего предмета - фольклористики. 
Особая роль в введении фольклористики в качестве предмета изучения принадлежит А. Н. Серову. Он инициирует открытие специализированных учреждений для подготовки профессионально подготовленных кадров в области фольклористики.

В настоящее время изучение традиционной культуры располагает научными знаниями, позволяющими рассматривать фольклор с разных сторон, - с точки зрения этнографии, этнологии, филологии, этнокультурологии, этнопедагогики, этномузыкологии, музыкальной фольклористики.

Подготовка специалистов осуществляется в области изучения музыкально-теоретических основ фольклора; рассмотрения развития фольклора в музыкально-историческом аспекте; изучения музыкально-этнографического бытования фольклора; изучения принципов этнопедагогического воспитания; освоения фольклорного исполнительства; музыкального воспитания средствами фольклора.

Целью фольклорной музыкальной педагогики является приобщение к общечеловеческим, духовным ценностям, в том числе - музыкальнофольклорной культуре.

На факультете дошкольной педагогики и психологии МПГУ уже много лет реализуется программа подготовки педагогов дошкольного образования, способных решать задачи формирования духовнонравственных культуры детей в процессе их ознакомления с истоками народной музыкальной культуры и приобщения к музыкальнофольклорной деятельности.

Накопившийся научный и практический опыт воплотился в создании системы формирования музыкально-фольклорной готовности студентов к работе с детьми, которая реализуется через комплекс специальных дисциплин («Вокально-хоровая деятельность», «Народное творчество», «Теория и методика работы с народной песней с практикумом») в процессе формирования у них компетенций в области исполнительской, теоретической и методической готовности, а также эмоционального положительнооценочного отношения к музыкально-фольклорной культуре для развития мотивации к активной творческой деятельности.

В программе решаются следующие задачи:

1) формирование у студентов духовно-нравственных идеалов; привитие и воспитание художественно-эстетического вкуса;

2) обогащение опыта студентов знаниями о фольклоре как педагогической системе межпоколенной передачи духовно-нравственных 
представлений через изучение музыкального народного творчества, его эстетических основ, форм бытования, жанровой системы;

3) развитие аналитических навыков в работе с фольклорным материалом и исследовательских умений в педагогической деятельности в процессе теоретического, практического и методического осмысления фольклорного творчества;

4) совершенствование музыкально-исполнительской культуры, овладение народной хореографической культурой и сценическим мастерством на основе сотворчества;

5) изучение принципов, форм, и методов организации процесса духовно-нравственного детей дошкольного возраста в музыкально-фольклорной деятельности.

Учебный процесс со студентами реализуется в следующих формах: лекционно-практической (получение основных знаний, практических умений и навыков в аудиторной и вне аудиторной (посещение концертов) и самостоятельной деятельности), фольклорно-исполнительской (освоение коммуникативных способов общения в музыкально-фольклорной деятельности), исследовательской (самостоятельное изучение теоретического, практического и методического материала), просветительской и проектной (осуществление концертной деятельности для различных возрастных и социальных групп, создание просветительских программ и сценариев).

Ожидаемые результаты процесса обучения по программе выражаются в готовности студентов к осуществлению духовно-нравственного развития детей дошкольного возраста в музыкально-фольклорной деятельности, которая содержит пять компонентов и определяется следующими группами критериев:

1. Мотивационно-личностная готовность к восприятию фольклора и его использования в духовно-нравственном развитии детей дошкольного возраста является показателем сформированности отношения студентов к народной культуре (восприятие как деятельность). Определяется по трем критериям: наличие общих эмоциональных способностей; положительное эмоционально-оценочное отношение к фольклорному искусству, выражаемое в суждениях; использование народного творчества в дошкольном музыкально-эстетическом воспитании.

2. Теоретическая готовность предполагает знания об истоках фольклорного искусства, где аккумулируются духовно-нравственные принципы и идеалы народа, и определяется наличием у студентов знаний 
истоков фольклорного искусства, жанровой системы и средств художественной выразительности музыкально-поэтического языка народных песен (познавательная деятельность). Определяется по пяти критериям: знание особенностей жанров фольклора; композиционных структур и композиционных приемов фольклорных текстов; средств художественной выразительности музыкально-поэтического языка народных песен; методов и приемов воспитания детей средствами фольклорного творчества; методов исследования музыкально-фольклорной деятельности детей.

3. Исполнительская готовность определяется умением студентов интегрировать фольклорные навыки (певческие, хореографические, драматические и т. п.) (исполнительская деятельность). Определяется по четырем критериям: владение певческо-речевой манерой пения; народной хореографией и сценическим поведением; игрой на народных инструментах; синкретизмом фольклорного исполнительства.

4. Научно-методическая готовность определяется умением студентов отбирать, анализировать фольклорный материал с точки зрения его художественной и духовно-нравственной ценности; редактировать и адаптировать песенный материал; организовывать музыкально-фольклорную деятельность на основе знаний принципов фольклорной работы с детьми дошкольного возраста (педагогическая, методическая деятельность). Определяется девятью критериями: умение анализировать фольклорный материал; подбирать, адаптировать фольклорный материал для работы с детьми дошкольного возраста; компоновать и воплощать фольклорный материал в сценические формы; варьировать и сочинять напевы и тексты; организовать музыкально-фольклорную деятельность детей в детском дошкольном учреждении; отбирать, анализировать, систематизировать полученные научные знания и практические умения; осуществлять наблюдение за детьми; применять диагностику развития основ музыкально-фольклорной культуры у детей; использовать, полученные навыки обработки полученных результатов исследовательской работы и ее апробации.

Комплекс теоретических знаний охватывает область этнографии, понимания философско-мировоззренческих и художественноэстетических, духовно-нравственных корней традиционной народной культуры, истории фольклора и его современного состояния, форм и стилей фольклорного исполнительства, принципов, методов, приемов фольклорной педагогики. 
Практические умения формируются в двух направлениях: в исполнительском (сольном и ансамблевом) и методическом.

В области фольклорного исполнительства студенты овладевают народно-певческим искусством (в синкретическом единстве слова, музыки и движения), которое синтезируется в пении, хореографии, инструментальной музыке, драматическом искусстве; осваивают комплекс необходимых навыков (моторно-двигательных, ритмо-ладоинтонационных, образно-эмоциональных, певческо-речевых); осваивают технику народного пения как средства раскрытия художественно-образного строя народных песен.

В области фольклорных методических умений студенты обучаются созданию эмоциональной творческой атмосферы в процессе фольклорной работы с детьми; владению детской аудиторией, навыками выразительного интонирования, образной речи, художественного общения; подбору, редакции и адаптации фольклорного материала на основе режиссерского, интонационного, музыкального анализов народных песен с учетом знаний возрастных особенностей детей дошкольного возраста; планированию процесса освоения произведения; компоновке фольклорного материала в блоки, сценические формы, концертные программы; организации музыкально-фольклорной деятельности детей совместно с воспитателями и родителями (в режимной и вне образовательной деятельности); осуществлению диагностики и исследовательской работы в области методики фольклорного воспитания детей.

Имеющийся на факультете дошкольной педагогики и психологии МПГУ опыт формирования у студентов духовно-нравственной культуры в процессе их подготовки к музыкально-фольклорной работе с детьми дошкольного возраста является уникальным и готов к дальнейшему распространению и внедрению в образовательную систему нашей страны.

\section{Литература}

1. Антонова, Г. В. Духовно-нравственное воспитание студентов в процессе изучения педагогических дисциплин в вузе / Г. В. Антонова, Н. В. Левченко, С. И. Маслов // Известия Тульского государственного университета. Гуманитарные науки. - 2014. - № 4.- С. 87-92.

2. Валеева, Р.А. Эстетическое воспитание студента вуза средствами интеграции искусств как фактор развития субъектности / Р. А. Валеева, С. В. Каркина // Образование и саморазвитие. - 2014. - № 3. - С. 51-54. 
3. Никольская, Е. В. Роль народной культуры в патриотическом воспитании студентов на факультете дошкольной педагогики / Е. В. Никольская // Дошкольное образование и профессиональная подготовка кадров: традиции и инновации. - Москва, 2017. - С. 69.

4. Никольская, Е. В. Формирование готовности студентов педагогических вузов к музыкально-фольклорной деятельности : монография / Е. В. Никольская. - Москва : Прометей, 2012. - 152 с.

5. Стерхова, Н. С. Эстетическое воспитание студентов педагогического вуза в контексте структурного анализа / Н. С. Стрехова // Актуальные проблемы гуманитарных и социально-экономических наук. 2012. - № 6. - C. 44-49. 
Алексеева Л. Ю., воспитатель ГБОУ «Школа № 1359» г. Москва

Янова С. В., воспитатель ГБОУ «Школа № 1359» г. Москва

\section{СТАНОВЛЕНИЕ НРАВСТВЕННО-ЦЕННОСТНЫХ ОТНОШЕНИЙ У ДЕТЕЙ МЛАДШЕГО ДОШКОЛЬНОГО ВОЗРАСТА В УСЛОВИЯХ ИГРОВОЙ ДЕЯТЕЛЬНОСТИ}

Аннотация. В статье рассматривается нравственно-ценностные отношения у детей младшего дошкольного возраста в условиях игровой деятельности. Авторами описаны особенности формирования нравственно-ценностных отношений, педагогические условия, способствующие эффективности процесса формирования нравственно-ценностных отношений, определены их методы.

Ключевые слова: нравственность, нравственно-ценностные отношения, духовно-нравственное развитие, нравственное сознание, нравственные чувства, нравственные мотивы, нравственное поведение, игровая деятельность.

\section{Alekseeva L. Yu., teacher of GBOU School No. 1359, Moscow \\ Yanova $S$. . teacher of GBOU School No. 1359, Moscow}

\section{FORMATION OF MORAL AND VALUE RELATIONS IN CHILDREN OF YOUNGER PRESCHOOL AGE IN THE CONDITIONS OF PLAY ACTIVITY}

Abstract. The article examines the moral and value relations in children of younger preschool age in the conditions of play activity. The authors describe the features of the formation of moral and value relations, pedagogical conditions that contribute to the effectiveness of the process of forming moral and value relations, and determine their methods.

Keywords: morality, moral and value relations, spiritual and moral development, moral consciousness, moral feelings, moral motives, moral behavior, game activity. 
Нравственность - такой уровень развития личности, при котором усвоенные нравственные ценности общества становятся императивом ее жизнедеятельности. Согласно определению Е. В. Субботского, нравственное воспитание - процесс формирования гармоничной личности, развития целостной ценностно-смысловой доминанты у детей дошкольного возраста.

Результатом и показателем успешности процесса нравственного воспитания личности является нравственное развитие. В нашем понимании оно представляет собой процесс качественных интеграционных изменений познавательно-когнитивной, эмоциональной и практически деятельностной сфер личности ребенка.

Необходимо отметить, что важнейшим первоначальным этапом становления нравственности как характеристики личности человека ученые считают дошкольный возраст.

В дошкольный период ребенок под руководством взрослых приобретает первый опыт нравственного поведения, отношения к близким, сверстникам, природе, вещам, усваивает моральные нормы общества.

Основные задачи нравственного воспитания дошкольников включают формирование у детей нравственных чувств, положительных навыков и привычек поведения, нравственных представлений и мотивов поведения.

В воспитании ребенка с первых лет жизни большое место занимает формирование нравственных чувств. В процессе общения со взрослыми воспитывается чувство привязанности и любви к ним, желание поступать в соответствии с их указаниями, делать им приятное, воздерживаться от поступков, огорчающих близких людей. Ребенок испытывает волнение, видя огорчение или недовольство его шалостью, оплошностью, радуется улыбке в ответ на свой положительный поступок, испытывает удовольствие от одобрения близких ему людей. Эмоциональная отзывчивость становится основой формирования у него нравственных чувств: удовлетворения от хороших поступков, одобрения взрослых, стыда, огорчения, неприятных переживаний от своего плохого поступка, от замечания, недовольства взрослого.

Вся жизнь ребенка-дошкольника пронизана игрой, только так он готов открыть себя миру и мир для себя. Игра является одной из основных форм организации процесса воспитания, обучения и развития в детском саду.

Игра - самая ценная деятельность для дошкольника, обеспечивающая ему ощущение свободы, подвластности вещей, действий, отношений, позволяющая наиболее полно реализовать «здесь и теперь», достичь состояния полного эмоционального комфорта, стать причастным к детскому обществу, построенному на свободном общении равных. 
В процессе сюжетно-ролевой игры развиваются духовные и физические силы ребенка; его внимание, память, воображение, дисциплинированность, ловкость. Кроме того, игра - это своеобразный, свойственный дошкольному возрасту способ усвоения общественного опыта. В игре формируются все стороны личности ребенка, происходят значительные изменения в его психике, подготавливающие переход к новой, более высокой стадии развития. Этим объясняются огромные воспитательные возможности игры, которую психологи считают ведущей деятельностью. Игра - явление многогранное, ее можно рассматривать как особую форму существования всех без исключения сторон жизнедеятельности коллектива. Столь же много оттенков появляется с игрой в педагогическом руководстве воспитательным процессом.

Воспитательное значение игры во многом зависит от профессионального мастерства педагога, от знания им психологии ребенка, учета его возрастных и индивидуальных особенностей, от правильного методического руководства взаимоотношениями детей, от четкой организации и проведения всевозможных игр.

Нравственно-ценностное отношение ребенка младшего дошкольного возраста возникает как непосредственное переживание ситуации во взаимодействии с окружающими людьми. Становление нравственно-ценностных отношений детей младшего дошкольного возраста происходит на основе эмоционально-оценочных предпочтений, развития их представлений о ценностных взаимоотношениях, реализации и накопления адекватных форм нравственно-ценностных действий. Игровая деятельность строится как система ситуаций педагогически организованного социального опыта. Содержание системы может быть реализовано в трех типах ситуаций: ситуации актуализации ценностного опыта у детей младшего дошкольного возраста (узнавание); ситуации обогащения опыта ценностных отношений (переживание); ситуации нравственного выбора ребенка (действие).

Формирование ценностного отношения к людям у детей младшего дошкольного возраста должно составлять фундамент программы воспитания.

В процессе социализации у ребенка складывается определенная модель мира, система собственных ценностных представлений. Ценностные ориентиры не просто усваиваются на когнитивном уровне со слов взрослых, а в процессе ценностного взаимодействия присваиваются им, становятся содержанием личности ребенка. 
Процесс становления ценностных отношений у детей младшего дошкольного возраста должен строиться с учетом механизма структурнофункционального единства основных компонентов ценностного отношения (эмоционально-оценочного, когнитивного, поведенческого).

Воспитательной основой процесса игровой деятельности у детей младшего дошкольного возраста должна быть ориентация воспитательного пространства на главные жизненные ценности. Использование специальной системы педагогически организованных ситуаций нравственно ценностного опыта обеспечивает включение младших дошкольников в нравственное взаимодействие и конструктивные ценностные взаимоотношения с другими людьми.

Задача воспитательного начала в ситуации нравственного - ценностного опыта - помочь ребенку выйти па определенное переживание собственных нравственных действий. Работа по воспитанию нравственно ценностных отношений у детей младшего дошкольного возраста должна строиться целенаправленно и пронизывать все сферы деятельности дошкольника.

Становление нравственно-ценностных отношений детей младшего дошкольного возраста требует гибкой тактики построения взаимодействия, которая представляет собой некоторое жизненное пространство, актуализирующее ценностные проявления ребенка. 
Eвcmaфbeва C. A., воспитатель высшей категории ГБОУ «Школа № 1359» г. Москва

Евстафьева К. C., учитель ГБОУ «Школа № 2054» г. Москвы, магистрант Московского педагогического государственного университета

\section{ГРАЖДАНСКО-ПАТРИОТИЧЕСКОЕ ВОСПИТАНИЕ ДОШКОЛЬНИКОВ НА ОСНОВЕ ПРОЕКТНОГО МЕТОДА}

Аннотация. В статье рассматривается вопрос о важности использования проектного метода в системе дошкольного образования для достижения гражданско-патриотического воспитания.

Ключевые слова: гражданско-патриотическое воспитание, проектный метод, дошкольное образование, дети дошкольного возраста.

Evstafyeva S. A. educator of the highest category of GBOU "School No. 1359" Moscow,

Evstafyeva K. S. teacher of the State Educational Institution "School No. 2054" of Moscow, master's student of the Moscow pedagogical State University

\section{CIVIL AND PATRIOTIC EDUCATION OF PRESCHOOL CHILDREN BASED ON THE PROJECT METHOD}

Abstract. The article discusses the importance of using the project method in the system of preschool education to achieve civil and patriotic education.

Keywords: civil and patriotic education, project method, preschool education, preschool children.

Воспитание патриотизма у подрастающего поколения всегда было и остается актуальным вопросом. В содержании ФГОС отмечается необходимость активизации процесса воспитания патриотизма дошкольников [1]. В этот период жизни человек особенно тянется к знаниям и хорошо их усваивает, и происходит процесс фор- 
мирования личности. Детское восприятие очень яркое и сильное, поэтому воспитание патриотизма в этом возрасте очень важно, оно оставляет след в памяти на всю жизнь.

Существуют различные определения такого понятия как «патриотизм». Г. Бакланов писал, что это «...не доблесть, не профессия, а естественное человеческое чувство». С. И. Ожегов определял патриотизм как «...преданность и любовь к своему Отечеству» [3]. Понять и осознать, что такое патриотизм дети могут уже в младшем возрасте. Помочь разобраться им в этом вопросе может такой актуальный метод, как проектная деятельность [5; 6].

Проектная деятельность развивает познавательный интерес, формирует навыки сотрудничества. Участвуя в проекте, ребенок ощущает себя значимым в группе сверстников, видит свой вклад в общее дело, радуется своим успехам и успехам товарищей.

Проектный метод - это осуществление замысла от момента его возникновения до его завершения с прохождением определенных этапов деятельности. Проектная деятельность дает возможность воспитывать «деятеля», а не «исполнителя», развивать волевые качества личности, навыки партнерского взаимодействия. Данный метод позволяет объединять различные образовательные области, что повышает качество образовательного процесса. А также позволяет объединить педагогов, детей и родителей, научить работать в коллективе, выстраивая план своей работы.

В настоящее время проекты различаются по тематике (творческие, информационные, игровые, исследовательские), по составу участников (индивидуальные, групповые, фронтальные), по срокам реализации (краткосрочные, среднесрочные, долгосрочные). В основе проекта лежит актуальность, цель, задачи, которые ставятся и достигаются в процессе проектной деятельности.

В канун празднования Дня Победы с детьми старшего дошкольного возраста был осуществлен гражданско-патриотический проект «Согреем памятью сердца». Целями проекта стало ознакомление детей с героическими подвигами участников Великой Отечественной войны и воспитание нравственно-патриотических чувств у дошкольников через систематизацию знаний о своей семье, а именно о тех, кто принимал участие в военных действиях. Решение поставленных задач осуществлялось на основе взаимодействия всех видов искусств. На наш взгляд 
именно искусство оказывает огромное влияние на формирование гражданско-патриотических качеств у детей дошкольного возраста, которые в силу своих возрастных особенностей воспринимают окружающий мир на основе накопления впечатлений и эмоций [2].

В ходе реализации данного проекта был оформлен уголок боевой славы, где были представлены атрибуты военной тематики: форма военнослужащего, боевые награды (ордена и медали), гильзы, котелок, фляжка, письма с фронта. Многие экспонаты выставки были предоставлены из семейных архивов родителями воспитанников.

Была организована выставка творческих работ (поделок, аппликаций, рисунков) детей, педагогов и родителей. В работах были отражены события военных действий и жизнь в тылу. Совместное творчество родителей с детьми принесло много удовольствия и радости всем участникам этого процесса. Дети с удовольствием принимали участие в конкурсе чтецов, посвященному Дню Победы.

В ходе работы над проектом широко использовались демонстрационные фото и видео материалы, интернет ресурсы. Большую помощь в организации работы по данному направлению оказал сайт Международной гражданско-патриотической акции «Рисуем Победу» [4]. Использование данной интернет-платформы позволяет представить свои творческие материалы и эссе любому желающему, и тут же получить диплом об участии. В ходе реализации проекта была осуществлена видеозапись концерта - поздравления ко дню Победы. Видеозапись праздничного выступления детей была передана в Центр Ветеранов. Саму запись концерта дети видели и были в полном восторге.

Подводя итог проделанной работе, сделаем следующие выводы: на конкретных фактах из жизни старших членов семьи (прадедушек и прабабушек, участников Великой Отечественной войны, их трудовых и фронтовых подвигах) ребята поняли, что значит любить свое Отечество, быть верным ему. Ведь Родина чтит своих героев, отдавших жизнь за счастье людей. Их имена увековечены в названиях городов и улиц.

Таким образом, мы видим, что проектный метод действительно актуален и является эффективным в организации образовательного процесса по формированию гражданско-патриотического воспитания дошкольников. 


\section{Литература}

1. Федеральный Государственный образовательный стандарт дошкольного образования: утвержден приказом Министерства образования и науки Российской Федерации от 17 октября 2013г., № 1155 / Министерство образования и науки Российской Федерации. - Москва : 2013.

2. Жукова, Г. Е. Роль искусства в нравственно-патриотическом воспитании на этапе дошкольной ступени образования / Г. Е. Жукова, В. Н. Суворова // Материалы Всероссийской научно-практической конференции «Рисуем Победу-2019». - Москва, 2019. - 102 с.

3. Ожегов, С. И. Толковый словарь-онлайн. [Электронный ресурс]. URL : https://slovarozhegova.ru (дата обращения : 10.04.2021).

4. «Рисуем Победу» [Электронный ресурс]. - URL : https://www. risuem- pobedu.ru (дата обращения : 10.04.2021).

5. Румянцева, Е. А. Проекты в ДОУ: практика обучения детей трехсеми лет. - Волгоград : Учитель, 2014.

6. Шкель, В. Ф. Метод проектов в образовательном процессе : учебно-методическое пособие / В. Ф. Шкель. - Саратов, 2010. - 124 с. 
Третьяков А. Л., доцент кафедры дошкольного образования Московского государственного областного университета, старший преподаватель кафедры социальной психологии Московского психолого-социального университета

\section{ПСИХОЛОГО-ПЕДАГОГИЧЕСКИЕ ОСНОВЫ РАЗВИТИЯ ДЕТЕЙ СТАРШЕГО ДОШКОЛЬНОГО ВОЗРАСТА}

Аннотация. В статье определяется психолого-педагогическая характеристика и специфика развития детей старшего дошкольного возраста. Определено, что в старшем дошкольном возрасте первое место среди психических познавательных процессов отводится памяти, развитие, которое создает возможности отрыва от имеющейся ситуации, а также возникает наглядно-образное мышление.

Ключевые слова: дети старшего дошкольного возраста, психологопедагогическая характеристика, дошкольное образование, специфика, педагогические условия.

Tretyakov A. L., Associate Professor at the Department of Preschool Education Moscow Region State University, Senior Lecturer at the Department of Social Psychology Moscow Psychological and Social University

\section{PSYCHOLOGICAL AND PEDAGOGICAL FOUNDATIONS OF THE DEVELOPMENT OF OLDER PRESCHOOL CHILDREN}

Abstract. The article defines the psychological and pedagogical characteristics and the specificity of the development of older preschool children. It has been determined that in senior preschool age, the first place among mental cognitive processes is given to memory, development, which creates opportunities for separation from the existing situation, and also visual-figurative thinking arises.

Key words: children of senior preschool age, psychological and pedagogical characteristics, preschool education, specificity, pedagogical conditions.

Старший дошкольный возраст - это особенный и, несомненно, важный 
период в развитии ребенка. В данном возрасте происходит перестройка всей психической жизни ребенка, а также его отношения к окружающему миру. В основе данной перестройки лежит возникновение внутренней психической жизни, а также внутренней регуляции поведения, о чем свидетельствую результаты современных исследований [1-10].

Задачи многостороннего исследования возрастного становления дошкольника изучали российские деятели науки Л. И. Божович, Л. С. Выготский, А. В. Запорожец, В. В. Зеньковский, М. И. Лисина, Р. С. Немов, С. Л. Рубинштейн, Д. Б. Эльконин и др. Специалисты по психологии считают, что «развитие личности - процесс формирования личности как общественного свойства индивидуума в итоге его социализации и воспитания». Владея природными анатомо-физиологическими посылами к становлению личности, в процессе социализации малыш вступает во взаимодействие с находящимся вокруг миром, овладевая достижениями народа. Формирующиеся в ходе сего процесса возможности и функции воспроизводят в личности исторически сформировавшиеся свойства человеческой натуры.

В возрасте пяти-семи лет дети приобретают уровень функционального и морфологического развития, который психологи часто называют «школьной зрелостью», что развивает критический этап развития, от которого будет зависеть будущая жизнь ребенка. Согласно мнению таких авторов, как Л. С. Выготского, Л. И. Божович, Е. О. Смирновой, старший дошкольный возраст - это время конца детства.

Если еще в раннем детстве поведение ребенка побуждается, а также направляется извне, и контролируется взрослыми, то в дошкольном возрасте ребенок сам начинает определять собственное поведение. Становление психической жизни ребенка, развитие познавательных психических процессов, а также формирование личности ребенка формируют познавательное развитие ребенка.

В старшем дошкольном возрасте интересы ребенка начинают смещаться от мира предметов к миру взрослых, так как ребенок вышел за пределы семьи, тем самым формируя в сознании образ взрослого не как конкретное лицо.

Психические познавательные процессы - это динамическое отражение действительности в разнообразных формах психических явлений, либо течение психического явления, которое имеет начало, развитие и конец. Психические процессы могут вызываться как внешними раздражителями, так и раздражителями, которые идут от внутренней среды 
организма человека. К психическим познавательным процессам можно отнести: восприятие, ощущение, представление, мышление, память и воображение. Психические познавательные процессы, как правило, обеспечивают формирование знаний, умений и способностей, также регуляцию поведения и деятельности человека [8].

В старшем дошкольном возрасте первое место среди психических познавательных процессов отводится памяти, развитие, которое создает возможности отрыва от имеющейся ситуации, а также возникает нагляднообразное мышление. Так как память носит непроизвольный характер, на момент старшего дошкольного возраста в процессе игры у ребенка складывается преднамеренное, произвольное припоминание и запоминание.

Как отмечал Ж. Пиаже, период от пяти-семи лет являет собой переход от сенсомоторного интеллекта к первоначальным формам логического мышления. Отечественные психологи не отрицают данную концепцию, а также считают, что основной задачей в изучении старшего дошкольного возраста является понимание истинного смысла развития ребенка и интеллектуальных возможностей. Интеллектуальное развитие ребенка дошкольного возраста гораздо выше, чем ранее считали психологи, поэтому, в условиях грамотного обучения дети достигают высоких результатов в развитии мышления.

Для детей старшего дошкольного возраста характерен высокий уровень познавательной потребности, поэтому дети задают много вопросов, которые отражают их стремление классифицировать предметы и явления, а также находить различные и общие признаки живого и неживого, прошлого и будущего опыта, понять законы зла и добра. В старшем дошкольном возрасте дети начинают спрашивать о смысле предметов и явлений, также у них формируется представление о жизни и смерти, что лежит в основе теоретического мышления.

Если говорить об интеллектуальных способностях ребенка старшего дошкольного возраста, то можно сделать вывод, что мышление переходит от наглядно-действенного к наглядно-образному, так как дети начинают овладевать наглядным моделированием. Модельная или схематическая форма мышления рассматривается как промежуточная между образным и логическим мышлением, предполагая навыки ребенка выделять существенные параметры ситуаций, опираясь при этом на схемы и модели, представленные во внешнем плане. В конце дошкольного возраста у детей наблюдается развитие форм понятийного и словесно-логического мышления.

В старшем дошкольном возрасте происходит активное овладение 
речью. Можно выделить основные направления речевого развития дошкольника: увеличение словаря, а также развитие грамматического строя речи; развитие феномена детского словотворчества, как процесса обогащения языковых и когнитивных структур; понижение эгоцентризма в речи; развитие общих функций речи; речь становится орудием общения; речь, как средство основной коммуникации, которая обретает связность и логичность построения; речь становится оружием мышления, средством перестройки психических процессов, а также компонентом регулирования и планирования поведения.

Деятельность в старшем дошкольном возрасте направляется и побуждается не отдельными, а связными мотивами и выстроенной системой мотивов. Столкновение различных тенденций к непосредственному действию, либо деятельность по примеру взрослого, как правило, приводит к появлению соподчинения мотивов и выделению второстепенных и главных. Появление иерархии мотивов говорит о том, что у дошкольника появилось волевое поведение.

В старшем дошкольном возрасте у детей происходит формирование самооценки и самосознания, в которые входит оценка собственных умений делать практическую работу, а также соблюдение моральных качеств, которые выражаются в подчинении правилам, принятым в определенной социальной группе. Наблюдается развитие тенденции к осуществлению деятельности неигрового характера, которая может быть выражением желания быть школьником, либо выполнять общественно значимую деятельность.

Немаловажные перемены происходят и в сфере самосознания дошкольника. Сформированность Я-концепции и самосознания характеризуется пониманием ребенком возможностей своего организма, умений, моральных свойств, переживаний. Малыш понимает особенности расположения к нему старших, способен расценить собственные заслуги, довольно самокритичен. Ему присущи переживания собственной значимости, убеждение в вероятности последующего продвижения. Продуктивная учебная практика подразумевает его адекватное отношение к собственным возможностям, итогам работы, поведению. В случае если у малыша завышено самомнение, то сложно рассуждать о субъективной готовности к школьному обучению. 
Уже позднее знание психологии ребенка, а также происхождение первоначального развития психики начало рассматриваться как бесценное средство познания человека и решения главных вопросов развития. Были сформулированы положения касательно главных черт общего детского развития:

- развитие осуществляется постепенно и последовательно, носит непрерывное поступательное движение вперед, однако приобретает прямолинейный характер;

- между духовным и физическим развитием наблюдается такая же связь, как и между волевой, эмоциональной и умственной сферой. грамотно построенный процесс воспитания обеспечивает гармоничное и всестороннее развитие;

- развитие ребенка осуществляется разными темпами в зависимости от особенностей развития ребенка;

- развитие может быть болезненным или вообще остановиться;

- нельзя зафиксировать детское развитие, а также «детство» должно себя изжить.

Как отмечал Д. Б. Эльконин, в старшем дошкольном возрасте, дети получают развитие направленности и активности. Он говорил о важности соподчинения мотивов, как выражения столкновения между тенденциями к действиям по образцу и непосредственным действиям. Также, автор говорил, что произвольность поведения - это результат подчинения собственных поступков, которые ориентируют их к образцу. Формирование такого типа поведения, а также процесс соподчинения мотивов - это новый виток в общем развитии детей, который было важно отметить.

Опираясь на вышеизложенные положения, мы можем сделать вывод, что развитие старших дошкольников понимается как связанные между собой процессы развития психических функций, а также когнитивных структур, коммуникативных и социальных качеств, включающих в себя появление в психике дошкольника новообразований, которые характерны для его возраста, обуславливающее последующее совершенствование.

Образование в области окружающей среды имеет огромное значение в экологическом обучении и воспитании детей, поэтому, в рамках данного исследования, под экологическим образованием мы будем понимать процессы формирования систем научного знания, убеждений и 
взглядов, которые могут обеспечить становление гражданской ответственности подрастающего поколения за состояние экологии мира.

Экологическое обучение, образование и воспитание детей дошкольного возраста, а также всего общества - это важная задача государственного уровня, которая включает в себя несколько этапов, которые охватывают систему обучения. Одним из направлений экологического обучения и воспитания является пропаганда идей охраны окружающей среды, основанных на гуманистических, патриотических, познавательных, эстетических и других мотивах.

Формирование экологической культуры личности - это стратегическая задача общества, а также цель образования, поэтому более точно говорить не о формировании экологической культуры, а о процессах экологизации культуры, как некой совокупности духовных ценностей, включающих в себя результаты деятельности человека, навыков, умений, уровня эстетического и нравственного развития, мировоззрения, правил поведения. Однако, в рамках данной работы мы будем придерживаться устоявшихся терминов.

Условия и принципы развития экологической культуры призывают решать комплексный подход воспитания личности, в процессе которого осуществляется развитие экологической ответственности личности через развитие осознания ценности и уникальности природы. Формирование культуры в рамках экологического образования является инструментом отработки новых форм социальной активности, которые сводятся к минимизации экологических рисков и обеспечивают безопасность жизнедеятельности.

Когда мы говорим об экологическом воспитании и обучении детей дошкольного возраста, важно сказать, что оно должно быть реализовано в системе общей воспитательной и образовательной работы с детьми, которое осуществляется в рамках ФГОС ДО (далее стандарт). Опираясь на Стандарт, воспитательный и образовательный процесс в ДОУ претерпевает значительные изменения. В первую очередь, отмечается такая особенность организации образовательной деятельности, как уход от занятий к повышению статуса игры, как основного вида деятельности ребенка дошкольника, а также включения методов проектной деятельности, наблюдений, игровых ситуаций, а также проблемных ситуаций.

При планировании работы по ознакомлению дошкольников с природой нужно применять комплексно различные способы, причем очень 
точно связывать их между собой. Выбор способов и целесообразность их применения ориентируются на возрастной потенциал дошкольников, направление воспитательно-образовательных задач, которые определяет педагог. Многообразие самих объектов и явлений природы, с которыми должен познакомиться ребенок, также предполагает применение всевозможных способов. К примеру, нереально сформировать у детей представления о способе существования домашнего кролика без исследований, рассматривания и изучения животного; с правилами по уходу за комнатными растениями малыши знакомятся в процессе труда, о свойствах снегопада и льда - при проведении экспериментов или игр. Оснащение и создание зоны природы - это немаловажное обстоятельство для педагогического планомерного процесса формирования у ребят познавательной способности в рамках экологического образования.

Процесс совместной деятельности ребенка и взрослого, построенный на правильном отношении, развивает интерес к живому миру, и может проявляться только при соблюдении условия добровольного участия детей в данной деятельности.

К совместной деятельности детей и взрослых в рамках экологического образования относят трудовую деятельность, которая обладает огромным образовательным потенциалом, расширяя кругозор и способствуя развитию наблюдательности; проектный метод; наблюдения за природой, в ходе которого происходит чувственное познание природы; экскурсии; игровую деятельность; беседы; применение наглядного моделирования.

\section{Литература}

1. Бахтина, Е. В. Межкультурный диалог в библиотеке / Е. В. Бахтина, Ю. Ф. Андреева, В. В. Орлов // Библиопанорама. - 2017. № 1. - С. 32-34.

2. Брянцева, М. В. Альтернативные формы противодействия антисоциальным проявлениям молодежных субкультур / М. В. Брянцева // Самоидентификация молодежи в социальном пространстве. Москва, 2009. - С. 68-78.

3. Головачев, В. С. Возможности межрегионального проектного взаимодействия учреждений образования и культуры в нравственноэстетическом воспитании дошкольников / В. С. Головачев // Вестник Чувашского государственного педагогического университета им. И. Я. Яковлева. - 2019. - № 5. - С. 143-150. 
4. Головачев, В. С. Новые формы взаимодействия учреждений образований и культуры на основе культурно-образовательных интернет-платформ / В. С. Головачев // Архитектура университетского образования: построение единого пространства знаний. - Санкт-Петербург, 2020. - С. 354-361.

5. Данилова С. С. Проблема реализации воспитательного потенциала семьи / С. С. Данилова, Е. М. Корж // Новое в психолого-педагогических исследованиях. - 2019. - № 3. - С. 167-170.

6. Емельяненкова, А. В. Индивидуально-психологические особенности руководителя как фактор творческого потенциала / А. В. Емельяненкова, О. В. Кобелева // Проблема творческого развития личности в XXI веке. - Ульяновск, 2004. - С. 240-241.

7. Колесникова, М. Н. Архитектура и дизайн библиотек : учебное пособие / М. Н. Колесникова, Е. В. Бахтина. - Санкт-Петербург : СПбГИК, 2016. - 128 с.

8. Коренева, Ю. В. Литературные экскурсии музеев как вид образовательного туризма / Ю. В. Коренева, К. С. Хосровян, О. В. Кобелева // Наука на благо человечества - 2018. - Москва, 2018. - С. 202206.

9. Корж, Е. М. Развитие подростка в современных условиях с учетом гендерных факторов / Е. М. Корж // Фельдштейновские чтения. Москва, 2017. - С. 51-57.

10. Dyachenko I. L. The estimation of possibilities of product and imported raw substitution / I. L. Dyachenko, V. Sh. Khetagurova, G. A. Bryukhanova, M. N. Sosnov, M. V. Bryantseva // Biosciences Biotechnology Research Asia. - 2015. - № 2. - Volume 12. - P. 1603-1613. 
Куланина И. Н., заведующая кафедрой эстетического воспитания детей дошкольного возраста, кандидат педагогических наук, доцент Московского педагогического государственного университет, член-корреспондент МАНПО

\section{НЕКОТОРЫЕ АСПЕКТЫ ДУХОВНО-НРАВСТВЕННОГО ВОСПИТАНИЯ ДЕТЕЙ ДОШКОЛЬНОГО ВОЗРАСТА}

Аннотация. В статье рассматриваются важные аспекты духовнонравственного воспитания детей дошкольного возраста как неотъемлемой части теории воспитания.

Ключевые слова: духовность, нравственность, духовно-нравственное воспитание, духовно-нравственные качества, механизм духовнонравственного воспитания.

Kulanina I. N.,

Head of the Department of Aesthetic Education of preschool Children, $\mathrm{PhD}$., Associate Professor, MPSU, Corresponding member of the MANPO

\section{SOME ASPECTS OF SPIRITUAL AND MORAL EDUCATION OF PRESCHOOL CHILDREN}

Abstract. The article considers important aspects of spiritual and moral education of preschool children as an integral part of the theory of education.

Keywords: spirituality, morality, spiritual and moral education, spiritual and moral qualities, the mechanism of spiritual and moral education

В настоящее время одной из наиболее важных тенденций современной стратегии воспитания является усиление внимания к сфере духовно-нравственного воспитания личности ребенка и создание условий для его реализации. Это отражено в государственных документах: Федеральном законе «Об образовании в Российской Федерации», «Национальной доктрине образования РФ», «Концепции духовно-нравственного развития и воспитания личности гражданина России в сфере общего образования», ФГОС ДО и др. 
В этой связи особую значимость приобретает работа по духовнонравственному воспитанию детей в ДОО, где в настоящее время ведется поиск различных вариантов и форм совершенствования воспитания детей. Поскольку в дошкольном возрасте происходит социализация ребенка, расширение круга его общения, когда требуется проявление личностной позиции, определяющейся принятыми духовно-нравственными ценностями.

Духовность и нравственность - основополагающие характеристики личности, проявляющиеся в деятельности и поведении. Духовность и нравственность гармонично взаимосвязаны и эти понятия необходимо рассматривать в согласованности и единстве. Нравственность - это то, как мы живем и действуем. Смыслы задает духовность, правила и способы действия - нравственность.

«Духовно-нравственное воспитание - это педагогически организованный процесс усвоения и принятия детьми базовых культурных и национальных ценностей многонационального народа Российской Федерации, освоение знаний и опыта, необходимого для мирного существования в обществе, формирование ценностных качеств в целях личностной самореализации, приобщения к культуре своей семьи, Родины, народа и социализации в современном обществе» (Н. Е. Щуркова).

Впервые идея духовно-нравственного воспитания ребенка была разработана основателем научной дошкольной педагогики Я. А. Коменским в работе «Материнская школа» (1633). В книге представлена программа воспитания благочестия и добродетелей ребенка дошкольного возраста и методические советы (по осуществлению этой программы). В воспитании благочестия выделены три компонента: формирование основ религиозных представлений; воспитание чуткости и благодарности детского сердца; развитие стремления жить духовной жизнью, исполнять заповеди. Задачи нравственного воспитания - это развитие добродетелей (умеренность, опрятность, почтительность, послушание, правдивость, справедливость, любовь и благотворительность, трудолюбие, молчание, терпение, услужливость, приветливость, скромность). «Воспитание сердца» (духовного качества) и направление воли ребенка к добру и правде (нравственные качества) с самого раннего возраста, является профилактикой развития пороков (своеволия, упрямства, дерзости, гордости, гнева, 
безрассудства, праздности и малодушия). Самым достойным украшением человека Я. А. Коменский называет приобретенную с детства привычку «охотно и с радостью заботиться о других».

Я. А. Коменский предлагает следующие методы духовно-нравственного воспитания: постоянный образец добродетели и благочестия со стороны взрослых; ограждение детей от всего порочного; своевременное и осторожное наставление; умеренная дисциплина; упражнение в делах благочестия, добром поведении, любви и благотворительности (например, опыта преодоления своих капризов, при проживании ситуаций, предполагающих нравственный выбор). Эти положения не потеряли актуальности и в настоящее время.

Я. А. Коменский отмечал, что условиями духовно-нравственного воспитания являются вера, праведная жизнь родителей и других окружающих ребенка взрослых, полнота духовной жизни семьи; не только житейское, но и духовное попечение о ребенке; наполненность детской жизни любовью, радостью и благими впечатлениями; целенаправленное духовное и нравственное воспитание ребенка с первых лет жизни.

Преемниками Я. А. Коменского в развитии традиционалистской парадигмы теории и методики духовно-нравственного воспитания детей дошкольного возраста стали И. Г. Песталоцци и Ф. Фребель. Великие ученые-педагоги называют главным средством духовно-нравственного воспитания ребенка - материнскую любовь, которая призвана постепенно распространить дух любви и доверия на весь круг семейной жизни», а затем возвысить дитя к «чистым чувствам истинной христианской веры и истинной христианской любви, ... с самой колыбели строя на человеческой основе нравственную и религиозную жизнь ребенка.

А. Бэн (шотландский психологог, педагог), считает, что в основе духовно-нравственного воспитания - авторитет общества, то есть различные формы внешнего принуждения. Ж.-Ж. Руссо видит основы духовно-нравственных качеств в любви к себе и отождествлении себя с другими.

Прогрессивные русские педагоги XIX в. (А.Н. Острогорский, Л. Н. Толстой, К. Д. Ушинский), ставили духовно-нравственное воспитание во главу угла всего воспитательно-образовательного процесса (которое осуществлялось семьей, школой, обществом) и опиралось на потребность в нравственной деятельности, возникающей из основных свойств духовной природы человека. Духовно-нравственные качества 
и чувства, начинаясь с симпатии к своей семье, в процессе интеллектуального развития переходят через любовь к своему и отечеству в любовь к человечеству.

Так, Л. Н. Толстой считал, что духовно-нравственные убеждения не внушаются ребенку насильственно, а вырабатываются им самим на основе свободного осмысливания моральных требований к личности. Рассматривал деятельность как средство нравственного воспитания.

Духовно-нравственное становление личности, формирование духовно-нравственных качеств рассматривается в трудах А. Н. Острогорского, в которых он говорит о единстве, органическом сочетании нравственных знаний и нравственного опыта. Ведущее значение в этом процессе ученый-педагог отдает семье, микроклимату в семье: «Семья самая ранняя и самая влиятельная пища, которой питается человеческий дух. Дети воспитываются той семейной жизнью, какая складывается». Он называет признаки микроклимата в семье, которые формируют духовно-нравственные качества ребенка: «Хорошая семейная атмосфера, забота, нравственная требовательность любящей матери. В общении с родителями ребенок расширяет свой кругозор, учась у них трудолюбию, справедливости, прямодушию, участию чужому горю». Теоретические основы духовно-нравственного воспитания в наследии А. Н. Острогорского сохраняют свою актуальность.

Проблеме духовно-нравственного воспитания в современном образовательном процессе посвящены исследования Ш. А. Амонашвили, А. А. Корзинкина, С. В. Пашкова, Т. П. Петраковой, А. Д. Солдатенкова, Н. Е. Щурковой и др.

Различные аспекты духовно-нравственного воспитания детей дошкольного возраста представлены в исследованиях О. А. Вороновой, Г. Г. Григорьевой, Н. Ф. Губановой, Г. Е. Жуковой, М.Б. Зацепиной, И. А. Каировой, Н. Ф. Космачева, Т. С. Комаровой, И.Н.Куланиной, В. И. Петровой, О. М. Потаповской, А. Н. Сидоровой и других ученых.

Вопросы духовно-нравственной составляющей в образовательной деятельности педагога освещаются в научных исследованиях В. А. Беляевой, С. В. Веретенниковой, .П.Гладкий, Т. П. Грибоедовой, Н. И. Джегутановой, О. Н. Кудиной, В. А. Сластенина.

В современной образовательной парадигме процесс духовно-нравственного воспитания дошкольников можно определить, как совокупность последовательных взаимодействий педагога и воспитанников, направленных на достижение должного уровня духовной культуры 
личности, проявляющейся в познавательной активности, нравственных качествах, эстетических вкусах, религиозных (моральных) убеждениях.

Духовно-нравственное воспитание как неотъемлемая часть теории воспитания, направленное на усвоение подрастающим поколением нравственных ценностей, обеспечивающих общественно значимую мотивацию и их ориентацию в разнообразных жизненных ситуациях, определяющих их поведение, поступки.

В процессе духовно - нравственного воспитания у личности формируется следующая система ценностей: индивидуально-личностные (жизнь человека, права ребенка, честь, достоинство); семейные (отчий дом, родители, семейный лад, родословная семьи, ее традиции); национальные (образ жизни, поведения, общения; Родина, святыни страны, национальная геральдика, родной язык, родная земля, народная культура, единство нации); общечеловеческие (биосфера как среда обитания человека, экологическая культура, мировая наука и культура, мир на Земле и т. д.).

Таким образом, целью и объектом духовно-нравственного воспитания является сердце человека, и в этом его отличие от умственного воспитания, целью и объектом которого является мышление, от эстетического - целью и объектом которого являются чувства и т. д.

Эффективность духовно-нравственного воспитания детей в условиях образовательной организации зависит как от социокультурной, так и от духовно-нравственной ситуации в обществе и микросреде.

Анализ научной литературы позволил нам представить ступени духовно-нравственное развитие и воспитание личности:

1. Духовно-нравственное развитие и воспитание начинается в семье с первых лет жизни. Ценности семейной жизни, взаимоотношения в семье проецируются на отношения в обществе и составляют основу поведения.

2. Осознанное принятие личностью традиций, ценностей, социальной и духовной жизни его города, района, республики. Через родных, друзей, природную среду и социальное окружение наполняются конкретным содержанием такие понятия, как «Отечество», «родная земля», «родной язык», «моя семья и род», «мой дом» и др.

3. Принятие культуры и духовных традиций многонационального народа Российской Федерации.

Основными принципами организации воспитания духовно-нравственных качеств у детей является: нравственный пример педагога; со- 
циально-педагогическое партнерство; индивидуально-личностное развитие; интегративность программ духовно-нравственного воспитания; социальная востребованность воспитания.

Педагогический смысл работы по духовно-нравственному становлению личности ребенка состоит в том, чтобы помогать ему продвигаться от элементарных навыков поведения к более высокому уровню, где требуется самостоятельность принятия решения и нравственный выбор. Например, милосердие как важное качество духовно-нравственного воспитания - это умение пожалеть несправедливо обиженного, слабого, маленького, больного, независимо от их внешней привлекательности; бескорыстно помочь нуждающимся без напоминания и подсказки; отказаться от чего-то значимого, интересного для ребенка.

В классификации, разработанной Г. И. Щукиной, представлены группы методов, направленные на духовно-нравственное воспитание: методы разностороннего воздействия на сознание, чувства и волю детей в интересах формирования у них духовных и нравственных взглядов и убеждений (методы формирования сознания личности): чтение и анализ притч, басен, назидательных рассказов; этические беседы; разъяснения; внушения; диспуты; пример; методы организации деятельности и формирования опыта общественного поведения; методы стимулирования поведения и деятельности.

Формы организации и выбор методов духовно-нравственного воспитания зависят от индивидуальных особенностей детей, при этом воспитательная работа должна проводиться как со всем коллективом, так и в индивидуальном порядке.

Духовно-нравственное воспитание включает знания (обогащение духовно-нравственными знаниями, представлениями и понятиями); способы деятельности (навыки и привычки и нормы правильного поведения, нравственного опыта); опыт творческой деятельности; опыт эмоционально-ценностного отношения.

Последовательность формирования духовно-нравственных основ осуществляется в соответствии с механизмом духовно-нравственного воспитания. Механизм духовно-нравственного воспитания: знания и представления + мотивы + чувства и отношения + навыки и привычки + поступки и поведение = духовно-нравственное качество. Данный механизм имеет объективный характер. Он проявляется всегда, при формировании любого качества личности. 
Результатом духовно-нравственного воспитания являются появление и утверждение в личности определенного набора духовно-нравственных качеств: нравственных чувств (совести, долга, веры, ответственности, гражданственности, патриотизма); нравственного облика (терпения, милосердия, кротости, незлобивости); нравственной позиции (способности к различению добра и зла, проявлению самоотверженной любви, готовности к преодолению жизненных испытаний); нравственного поведения (готовности служения людям и Отечеству, проявления духовной рассудительности, послушания, доброй воли).

Социально-педагогическими условиями воспитания духовно-нравственных качеств у детей являются внутренние (обеспечение самоопределения, рефлексия духовно-нравственных ценностей, самореализация в совместной творческой благотворительной деятельности); внешние (организация содружества, сотворчества в разнообразных видах совместной социально-педагогической внеучебной деятельности, взаимодействие с родителями и субъектами социальной среды).

Из сказанного выше следует, что духовность и нравственность являются важнейшими, базисными характеристиками личности. Духовность определяется как устремленность личности к избранным целям, ценностная характеристика сознания. Нравственность представляет собой совокупность общих принципов поведения людей по отношению друг к другу и обществу. В сочетании они составляют основу личности, где духовность - вектор ее движения (самовоспитания, самообразования, саморазвития), она является основой нравственности. 
Суркова О. В.,

директор МАУДО «ДШИ № 1» г. Шумерля

\title{
ПРОЕКТНАЯ ДЕЯТЕЛЬНОСТЬ В ДЕТСКОЙ ШКОЛЕ ИСКУССТВ КАК СРЕДСТВО ДУХОВНО-НРАВСВЕННОГО ВОСПИТАНИЯ МОЛОДОГО ПОКОЛЕНИЯ
}

\begin{abstract}
Аннотация. В статье представлен опыт работы коллектива Детской школы искусств № 1 г. Шумерля Чувашской Республики по созданию воспитательной среды школы, которая объединяет урочную, внеклассную и внешкольную деятельность для гармонично развитой личности. Автор статьи приводит примеры проектной деятельности, социального партнерства, проведения конкурсов и различных мероприятий в данном направлении. Все мероприятия выстраиваются в единую систему работы школы по формированию духовно-нравственного воспитания обучающихся, в которой само искусство становится основным и ключевым моментом.
\end{abstract}

Ключевые слова: искусство, духовно-нравственное воспитание, детская школа искусств, обучающиеся.

Surkova O. $V$., Director of the MAUDO "DSHI No. 1" of Sumerlya

\section{PROJECT ACTIVITY AT THE CHILDREN'S ART SCHOOL AS A MEANS OF SPIRITUAL AND MORAL EDUCATION OF THE YOUNGER GENERATION}

Abstract. The article presents the experience of the team of the Children's Art School No. 1 of the city of Sumerlya, Chuvash Republic, in creating an educational environment of the school, which combines regular, extracurricular and extracurricular activities for a harmoniously developed personality. The author of the article gives examples of project activities, social partnership, holding competitions and various events in this direction. All events are built into a single system of the school's work on the formation of spiritual and moral education of students, in which art itself becomes the main and key moment.

Keywords: art, spiritual and moral education, children's art school, students. 
В образовательной системе Российской Федерации по обучению и воспитанию подрастающего поколения очень большое значение имеет деятельность Детских школ искусств. В дорожной карте по перспективному развитию ДШИ на 2018-2022 гг. одним из целевых ориентиров является пополнение рядов грамотной зрительской и слушательской аудитории театров, концертных и выставочных залов, где ДШИ выступает ядром в формировании гармоничного, духовно развитого российского общества.

Педагогический коллектив Детской школы искусств № 1 г. Шумерля согласно Федеральным государственным требованиям старается выстраивать воспитательную систему таким образом, чтобы искусство являлось объединяющим звеном урочной, внеклассной и внешкольной работы. На первый план в этом направлении выходит проектная деятельность. В МАУДО «ДШИ № 1» г. Шумерля успешно реализуются долгосрочные проекты «Милость сердца» (формирование толерантного отношения к различным социальным группам общества, воспитание чувства сострадания), «Колокола памяти», посвященный Победе в Великой Отечественной войне 1941-1945 гг., «Музыкальная галерея» (популяризация классической музыки и творчества композиторов), «Дети - детям» (повышение духовно-нравственного развития детей посредством культурного просветительства), «Наполним музыкой сердца», посвященный дню славянской письменности и культуры, «Литературно-театральный клуб «Вдохновение», «Художественная галерея» и др. Мероприятия в рамках проектов становятся яркими культурными событиями не только школы, города, но и на уровне республики и всегда несут в себе духовно-нравственное начало. Например, ежегодно большим хоровым концертом Детской школы искусств празднуется в городе Шумерля День славянской письменности и культуры. На хоровой концерт коллективов ДШИ приглашается настоятель храма преподобного Серафима Саровского протоиерей В. Ильин, который выступает с поздравительными словами и отмечает важность праздника как сохранения исторических, духовнонравственных и культурных традиций России. Так же Детская школа искусств неоднократно выступала социальным партнером в реализации православных проектов. Например, проекты победи- 
тели Международного грантового конкурса «Православная инициатива» библиотеки-филиала № 1 им. С. Я. Маршака г. Шумерля «Я читаю и творю» и «Улыбка веры», проект общественной организации «Союз женщин Чувашии» «Верить-любить-творить».

Более пяти лет ДШИ г. Шумерля эффективно сотрудничает с Чувашской республиканской общественной организацией «Культурновыставочный центр «Радуга» г. Чебоксары. Совместно реализованный социально-творческий проект «Караван искусств», способствовал приобщению населения малого города к мировому художественному наследию, формированию духовно-нравственного облика посредством выставок репродукций картин знаменитых художников. В выставочном пространстве нашей школы состоялось четыре выставки репродуктивных картин русских и зарубежных мастеров живописи: «Поэзия русского пейзажа», «Священные образы в живописи», «Традиции и нравы русского народа», «Шедевры французских импрессионистов». Каждая выставка презентовалась зрителям через синтез художественного, театрального и музыкального искусств.

Интегрированная форма проведения экскурсий была высоко оценена руководством КВЦ «Радуга» и отмечена как новая форма реализации проекта. Всего в рамках проекта «Караван искусств» было проведено 106 экскурсий, которые посетили более 1600 человек. Это школьники города, представители городского совета ветеранов, родительской и педагогической общественности, члены городского общества художников, члены союза художников Чувашии и России, жители и гости города Шумерля.

Высокую оценку мероприятиям дали представители городского совета ветеранов, написав в книге отзывов: «Выражаем большую благодарность за мероприятие, которое показало сплоченную работу всех преподавателей, воспитанников школы искусств. Это мероприятие оставило большое впечатление от синтеза искусств». Председатель Совета ветеранов города Шумерля Л. В. Григорьева выразила слова благодарности организаторам и юным экскурсоводам выставок за возможность прикоснуться к искусству, за проникновенное и патриотическое отношение к культурно-историческим ценностям.

В 2019 г. сотрудничество с КВЦ «Радуга» продолжилось новым совместным проектом «Моя семья в истории Великой Победы». В рамках проекта в картинной галерее г. Шумерля экспонируются уникальные 
выставки из фондов культурно-выставочного центра «Радуга» при поддержке Фонда президентских грантов.

В 2021 г., объявленным в Чувашской Республике годом, посвященным трудовому подвигу строителей Сурского и Казанского оборонительных рубежей, в Детской школе искусств № 1 г. Шумерля дан старт Городскому социально-выставочному проекту «Сурский рубеж. Взгляд юного художника», который реализуется совместно с Советом ветеранов г. Шумерля.

В рамках проекта в Детской школе искусств организован арт-холл «Сурский рубеж: незабытый подвиг». Арт-холл является площадкой, где ребята и преподаватели школы представляют свои активности, демонстрируя свое творчество в музыкальном, изобразительном, театральном искусстве. За первое полугодие 2021 г. тематические мероприятия арт-холла посетили все обучающиеся школы, их родители и почетные гости: представители кабинета министров Чувашской Республики, депутаты Государственного Совета Чувашской Республики, представители бизнес-сообщества Чувашии, администрации г. Шумерля и др. Гости отметили актуальность тематики арт-холла, где царит особая творческая атмосфера, ориентированная на сопричастность и уважение к героическому прошлому наших потомков.

Педагогический коллектив нашей школы старается выстраивать воспитательную систему, которая неразрывно связана с семейным воспитанием, где узловым моментом становится искусство. Например, проект по проведению городского фестиваля семейного творчества «Творческий я, творческая моя семья», где семья выступает творческой командой презентуя зрителям свое творчество в различных видах искусства. А уже ставший традиционным семейный просмотр спектаклей в исполнении обучающихся театрального отделения Детской школы искусств собирает полный зал зрителей в Международный день семьи. С успехом прошли премьеры спектаклей по пьесе К. Климовски «Дыня» и трагикомедии О. Ширеновой «Беготня вокруг коня». Именно такие культурные впечатления ненавязчиво передают нравственную установку, по-настоящему обогащают, воспитывают и объединяют детей и их родителей.

Еще одним направлением работы по воспитанию духовно-нравственного молодого поколения является проекты по организации и проведению Детской школой искусств конкурсов, целью которых является предоставление творчества ребенка через соприкосновение духовно- 
культурных произведений, событий, традиций России. Это открытый зональный конкурс юных исполнителей «Сурские узоры» памяти С. В. Кутлеевой и открытый городской очный конкурс изобразительного искусства «Моя Россия - моя страна!» им. В. И. Сапожникова.

Описанная работа детской школы искусств по созданию наиболее благоприятных условий для использования потенциала искусства через проектную деятельность является эффективным средством по формированию и развитию этических принципов и идеалов в целях духовнонравственного воспитания молодого поколения и становится одним из звеньев института общественного воспитания. 
Жукова Г.Е.,

кандидат педагогических наук, доцент кафедры эстетического воспитания ФДПиП Московского педагогического государственного университета

\section{МЕТОДЫ, ФОРМЫ И СРЕДСТВА НРАВСТВЕННОГО ВОСПИТАНИЯ ДЕТЕЙ ДОШКОЛЬНОГО ВОЗРАСТА}

Аннотация: В статье рассматривается вопрос нравственного воспитания детей дошкольного возраста, его важность и значение для современной системы образования, а также акцентируется внимание на методах, формах и средствах, используемых в данном процессе.

Ключевые слова: нравственное воспитание, дети дошкольного возраста, методы, формы, средства.

Zhukova G. E.,

$\mathrm{PhD}$, Associate Professor of the Department of Aesthetic Education FDPiP MPSU

\section{METHODS, FORMS AND MEANS OF MORAL EDUCATION PRE- SCHOOL CHILDREN}

Abstract. The article considers the issue of moral education of preschool children, its importance and significance for the modern education system, and also focuses on the methods, forms and means used in this process.

Key words: moral education, preschool children, methods, forms, means.

Современная система образования представляет собой многоуровневое пространство. Это достаточно сложный процесс, который создан для формирования у обучающихся желаний, потребностей и умений приобретать новые знания, освоению новых форм деятельности и реализация собственных интеллектуальных возможностей. Несомненно, что во всей этой системе важная роль отводится дошкольной ступени. Основной задачей современной системы дошкольного образования, согласно Федеральном Государственном Образовательном стандарте Дошкольного Образования (ФГОС ДО), является создание новой системы ценностей, способствующей становлению нравственной культуры ребенка, формированию гуманистически направленной личности [7]. В период политических и экономических реформ в нашей стране возник 
определенный ценностный вакуум, бездуховность, низкий уровень личностной культуры как способа передачи духовных ценностей, которые привели к потребности акцентировать внимание на нравственном воспитании. В связи с этим проблема нравственного воспитания детей дошкольного возраста является весьма актуальной и в тоже время сложной [2]. При все разнообразии применяемых педагогических методик и практик наблюдается рост детской агрессии, эмоционального равнодушия и сосредоточенности на собственных интересах. Отбор и рациональное использование разнообразных методов нравственного воспитания личности является одной из главных задач, которую ставят перед собой педагоги дошкольных образовательных организаций [1].

ФГОС ДО рассматривает процесс нравственного воспитания как одно из направлений личностного развития ребенка-дошкольника. Федеральный государственный образовательный стандарт дошкольного образования направлен на объединение обучения и воспитания в целостный образовательный процесс; формирование духовно-нравственных и социокультурных ценностей и принятых в обществе правил и норм поведения в интересах человека, семьи, общества; формирование общей культуры личности детей, в том числе ценностей здорового образа жизни, развития их социальных, нравственных, эстетических, интеллектуальных, физических качеств, инициативности, самостоятельности и ответственности ребенка, формирования предпосылок учебной деятельности.

Следовательно, в общей системе нравственного воспитания важное место занимает группа методов, форм и средств, направленных на формирование соответствующего уровня нравственности у детей дошкольного возраста.

Проблема нравственно-эстетического воспитания рассматривались в трудах Л. С. Выготского, Д. Б. Эльконина, Л. И. Божович, А. В. Запорожца и др. Среди современных исследователей, которые занимались вопросами нравственного воспитания можно выделить В. В. Попова, О. С. Богданова, Л. Р. Болотина, В. И. Логинова, Л. И. Романова и др.

По мнению С. А. Козловой и Т. А. Куликовой, нравственное воспитание - это целенаправленный процесс приобщения детей к моральным ценностям человечества и конкретного общества [4]. В свою очередь Б. Т. Лихачев определяет нравственную воспитанность и невоспитанность как качества, которые напрямую зависят социальных условий [5]. В исследованиях И. Ф. Свадковского указыва- 
ется на то, что нравственные чувства - это эмоциональные ощущения, переживания, возникающие у ребенка в процессе реальных нравственных отношений и взаимодействий [6].

Во ФГОС ДО заложена Концепция духовно-нравственного развития и развития гражданина России. Данный вопрос рассматривается в аспекте ценностного и деятельностного подходов. Одним из принципов ФГОС ДО является приобщение детей к социокультурным нормам, традициям семьи, общества и государства [7]. Решение данного вопроса будет успешным, если педагог в своей работе будет учитывать возрастные особенности дошкольников, на основе которых будут определено содержание, формы, методы обучения и воспитания.

И. Ф. Харламов определяет методы нравственного воспитания рассматривая проблему нравственного воспитания следующим образом.

\begin{tabular}{|c|c|c|}
\hline 1. & Приучение & $\begin{array}{l}\text { Предусматривающий организацию планомер- } \\
\text { ного и регулярного выполнения воспитанни- } \\
\text { ками определенных действий с элементами } \\
\text { обязательности, принуждения с целью форми- } \\
\text { рования конкретных привычек в поведении. }\end{array}$ \\
\hline 2. & Упражнение & $\begin{array}{l}\text { Обеспечивает выработку и закрепление необ- } \\
\text { ходимых навыков и привычек, использование } \\
\text { навыков и привычек на практике. }\end{array}$ \\
\hline 3. & Стимулирование & $\begin{array}{l}\text { Поощрение деятельности воспитанников с по- } \\
\text { мощью положительной оценки их поведения. }\end{array}$ \\
\hline 4. & Руководство & $\begin{array}{l}\text { Руководство деятельностью со стороны педа- } \\
\text { гога. }\end{array}$ \\
\hline 5 . & Торможение & $\begin{array}{l}\text { Выражаются в виде порицания, предупрежде- } \\
\text { ния, предъявления повышенных требований к } \\
\text { личности воспитанника. }\end{array}$ \\
\hline 6. & Самовоспитание & $\begin{array}{l}\text { Способ деятельности и установки на данную } \\
\text { деятельность с целью совершенствования } \\
\text { образа «Я - реальный» и создания образа «Я - } \\
\text { идеальный». }\end{array}$ \\
\hline 7. & $\begin{array}{l}\text { Объяснительно-ил- } \\
\text { люстративный }\end{array}$ & $\begin{array}{l}\text { Применение изученного осуществляется на ос- } \\
\text { нове образца или правила. Деятельность воспи- } \\
\text { танников носит алгоритмический характер, т. } \\
\text { е. выполняется по инструкции, предписанию, } \\
\text { правилам в аналогичных, сходных с показан- } \\
\text { ным образцом, ситуациях. }\end{array}$ \\
\hline
\end{tabular}




\begin{tabular}{|l|l|l|}
\hline 8. & $\begin{array}{l}\text { Проблемно- ситуа- } \\
\text { тивный }\end{array}$ & $\begin{array}{l}\text { Побуждает личность систематизировать усво- } \\
\text { енные нравственные знания и соотносить их с } \\
\text { избранными формами поведения. }\end{array}$ \\
\hline
\end{tabular}

В своих исследованиях Г. И. Щукина, в контексте нравственного воспитания, выделяет три группы методов [8, с. 131].

\begin{tabular}{|c|l|l|}
\hline 1. & $\begin{array}{l}\text { Методы формирования созна- } \\
\text { ния }\end{array}$ & $\begin{array}{l}\text { Рассказ, объяснение, разъяснение, } \\
\text { лекция, этическая беседа, увеще- } \\
\text { вание, внушение, диспут, доклад, } \\
\text { пример }\end{array}$ \\
\hline 2. & $\begin{array}{l}\text { Методы организации деятель- } \\
\text { ности и формирования } \\
\text { опыта поведения }\end{array}$ & $\begin{array}{l}\text { Упражнение, поручение, воспиты- } \\
\text { вающие ситуации }\end{array}$ \\
\hline 3. & Методы стимулирования & $\begin{array}{l}\text { Соревнование, поощрение, } \\
\text { наказание }\end{array}$ \\
\hline
\end{tabular}

Формы организации и методы нравственного воспитания варьируются от индивидуальных особенностей детей. По мнению Г. М. Коджаспировой, применяются как фронтальные, групповые, так и индивидуальные формы организации воспитательного процесс [3, с. 156].

Средства нравственного воспитания дошкольников можно объединить в несколько групп.

\begin{tabular}{|c|c|c|}
\hline $\begin{array}{l}\text { Первая } \\
\text { группа }\end{array}$ & $\begin{array}{l}\text { Карпинская } \\
\text { Н. С. }\end{array}$ & $\begin{array}{l}\text { Группа художественных средств, к которым } \\
\text { относится художественная литература, изоб- } \\
\text { разительное искусство, музыка, кино, диа- } \\
\text { фильмы, мультфильмы, способствующие по- } \\
\text { вышению познаваемых моральных явлений. } \\
\text { Использование художественных средств по- } \\
\text { казывает, что дети живо, эмоционально и до- } \\
\text { верчиво воспринимают читаемые им сказки, } \\
\text { стихи, рассказы, рассматривают иллюстрации } \\
\text { к книгам. Художественные средства наиболее } \\
\text { эффективны при формировании у детей мо- } \\
\text { ральных представлений и воспитании чувств. }\end{array}$ \\
\hline $\begin{array}{l}\text { Вторая } \\
\text { группа }\end{array}$ & $\begin{array}{l}\text { Николаева } \\
\text { С. Н. }\end{array}$ & $\begin{array}{l}\text { Средство нравственного воспитания, как при- } \\
\text { рода. Воздействие природы на нравственную } \\
\text { сферу детей 5-7 лет многогранно и при соот- } \\
\text { ветствующей педагогической организации } \\
\text { становится значимым способом воспитания } \\
\text { чувств и поведения, дает возможность вызы- }\end{array}$ \\
\hline
\end{tabular}




\begin{tabular}{|l|l|l|}
\hline & & $\begin{array}{l}\text { вать у дошкольников гуманные чувства, жела- } \\
\text { ние заботитья о тех, кто слабее, кто нужда- } \\
\text { ется в помощи, защищать их, что в итоге спо- } \\
\text { собствует формированию у ребенка уверенно- } \\
\text { сти в себе. }\end{array}$ \\
\hline $\begin{array}{l}\text { Tретья } \\
\text { группа }\end{array}$ & Крохина С. Ю. \\
\hline $\begin{array}{l}\text { Четвер- } \\
\text { тая } \\
\text { группа }\end{array}$ & Листенная деятельность - игра, труд, уче- \\
& $\begin{array}{l}\text { ние, художественная деятельность. Каждый } \\
\text { вид деятельности имеет свою специфику, вы- } \\
\text { полняя функцию средства нравственного вос- } \\
\text { питания. Повседневная деятельность до- } \\
\text { школьников 5-7 лет состоит из обучения, } \\
\text { игры, детского творчества. }\end{array}$ \\
\hline & $\begin{array}{l}\text { Общение большое практическое значение, так } \\
\text { как позволяет оценить влияние нравственного } \\
\text { воздействия на ребенка в процессе его обще- } \\
\text { ния с другими детьми и взрослыми. Так же } \\
\text { она выделяет еще одно средство нравствен- } \\
\text { ного воспитания - это окружение (семья, пе- } \\
\text { дагоги, воспитатели, сверстники), которое } \\
\text { оказывает огромное влияние на формирова- } \\
\text { ние моральных установок ребенка }\end{array}$ \\
\hline
\end{tabular}

На основании вышесказанного можно сделать вывод, что в ходе нравственного воспитания детей дошкольного возраста происходит реализация задач по становлению нравственной культуры ребенка, формированию гуманистически направленной личности, развитию нравственных чувств и формированию нравственного поведения на основе использования определенных методов, форм и средств организации данного процесса.

\section{Литература}

1. Алиева, Ш. Г. Социальное развитие дошкольников / Ш. Г. Алиева // Молодой ученый. - 2014. - № 2. - С. 714.

2. Жукова, Г. Е. Роль искусства в нравственно-патриотическом воспитании на этапе дошкольной ступени образования / Г. Е. Жукова, В. Н. Суворова // Материалы Всероссийской научно-практической конференции «Рисуем Победу-2019». - Москва, 2019. - 102 с.

3. Коджаспирова, Г. М. Педагогика : учебник / Г. М. Коджаспирова. Москва : КНОРУС, 2010. - 740 с. 
4. Козлова, С. А. Дошкольная педагогика : учебное пособие / С. А. Козлова, Т. А. Куликова. - 2-е издание. - Москва : Академия, 2000. - $416 \mathrm{c}$.

5. Лихачев, Б. Т. Педагогика : курс лекций / Б. Т. Лихачев. - Москва : ЮРАЙТ-М, 2001. - 646 c.

6. Свадковский, И. Ф. Нравственное воспитание / И. Ф. Свадковский. - Москва : Академия, 2011. - 144 с.

7. Федеральный государственный образовательный стандарт дошкольного образования: утвержден приказом Министерства образования и науки Российской Федерации от 17 октября 2013г., № 1155 / Министерство образования и науки Российской Федерации. - URL : http://www.consultant.ru/document/cons_doc_LAW_154637/1ad1a834f 2604827f926f8d5cce7251c500a26cd/ (дата обращения : 15.04.2021).

8. Щукина, Г. И. Психолого-педагогические основы обучения и воспитания школьников / Г. И. Щукина // Труды и дни. - Санкт-Петербург, 1997. - 335 c. 
Суворова В. Н.,

магистрант кафедры эстетического воспитания детей дошкольного возраста ФДПиП Московского педагогического государственного университета

\section{МЕТАМЕТОДИЧЕСКИЙ ПОДХОД В РЕАЛИЗАЦИЯ ПРОЕКТОВ ГРАЖДАНСКО-ПАТРИОТИЧЕСКОЙ НАПРАВЛЕННОСТИ В ОБРАЗОВАТЕЛЬНОЙ ОРГАНИЗАЦИИ}

Аннотация. В статье рассматривается вопрос о гражданско-патриотическом воспитании средствами проектной деятельности на основе метаметодического подхода в образовательной организации.

Ключевые слова: гражданско- патриотическое воспитание, проектная деятельность, метаметодика.

Suvorova $V . N$.

Master's student of the Department of Aesthetic Education of preschool children of the FDPiP Moscow Pedagogical State University

\section{METAMETODIC APPROACH TO PROJECT IMPLEMENTATION CIVIL-PATRIOTIC ORIENTATION IN AN EDUCATIONAL ORGANIZATION}

Abstract. the article deals with the issue of civil and patriotic education by means of project activities based on a metametodic approach in an educational organization.

Key words: civil and patriotic education, project activity.

Гражданско-патриотическое воспитание в нашей стране достаточно трудно, практически невозможно, осуществлять без учета политического, идеологического и социально - психологического и образовательно-воспитательного потенциала всех видов искусства [1]. В отечественной системе образования накоплен значительный опыт формирования гражданских и патриотических основ, которые стимулируют эмоциональнообразную, нравственно-эстетическую, патриотическую и творческую активность. Современные исследования данного направления, в системе среднего образования, посвящены 
изучению механизмов приобщения обучающихся к изучению истории страны, культуре, социальной жизни своего Отечества. Решение всех поставленных задач гражданско-патриотического воспитания осуществляется с помощью конкретных средств и методов. Их можно разделить на несколько групп.

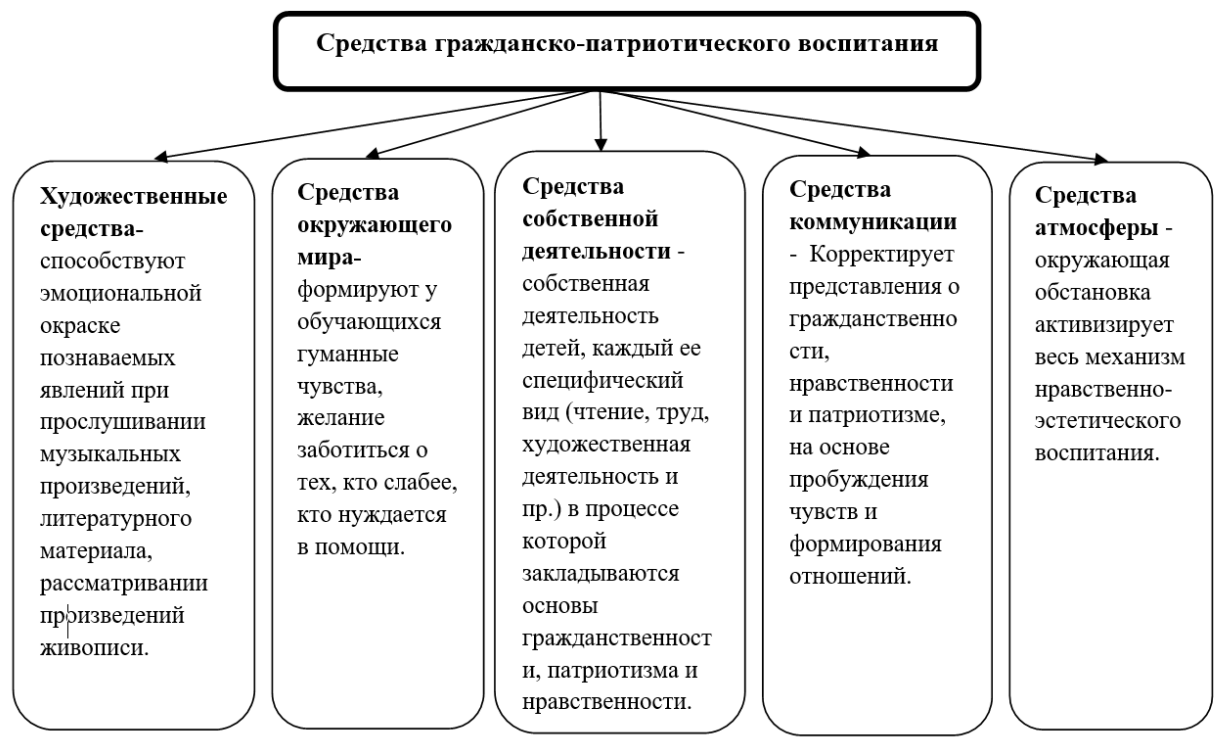

Все средства гражданско-патриотического воспитания будут эффективными в сочетании с адекватными методами. Самым важным из них является метод наблюдений в окружающей действительности. Стоит отметить, что, если педагог организует работу по гражданско-патриотическому воспитанию только в форме наблюдений, он очень ограничит круг знаний и представлений у его участников. Данную задачу педагог сможет решить, если умело будет сочетать наблюдение с чтением художественной литературы, прослушиванием музыкального материала и при знакомстве с произведениями живописи, просмотром тематических видео отрывков и презентаций и т. д.

Изучив данную проблему, мы пришли к выводу о том, что необходимо повышать содержательную, эмоционально-эстетическую и познавательную наполняемость гражданско-патриотического воспитания в современной образовательной организации. Данный процесс может 
осуществляться на основе использования различных средств, методов и форм психолого-педагогического воздействия искусства. Роль музыки, литературы и живописи в системе гражданско-патриотического воспитания очень велика. Участвуя в таких формах образовательной деятельности как беседа, досуг праздник, акция, проект, где все виды искусства представлены достаточно широко, позволяют не только ярко выплеснуть свои эмоции каждому участнику, но и заложить фундамент гражданственности, нравственности и патриотизма [3, с. 38-39].

Решение поставленных задач гражданско-патриотического воспитания в современной образовательной организации на основе синтеза искусств, требует новых, конструктивных подходов, а, следовательно, и, установления межпредметных связей между всеми видами образовательной деятельности и формами ее реализации. В исследовании И. М. Титовой данный подход обозначается как метаметодика, и характеризуется как диалог предметных методик. Этот диалог направлен на выявление и продуктивное использование интеграции. В данном случае имеется в виду такая интеграция, которая исходит из учета содержательной специфики и развивающего потенциала конкретных учебных предметов, в направлении от частного к общему (в отличие от дидактики, где действие разворачивается преимущественно в обратном порядке: от общего к частному) [6, с. 92].

В тоже время А. П. Валицкая определяет метаметодику как «момент осмысления частных методов, поиска общего пути к достижению единой цели» [2, с. 3].

Наиболее распространенное и широкое понимание метаметодики дает А. Б. Афанасьева, обозначая ее, как диалог частных методик. В этом случае взаимодействие происходит на уровне общности интересов и поставленных целей, сопоставимости художественных и жизненных образов, языков, культуры, организационно-деятельностных методов, способов и форм обучения. Данный подход может осуществляться как внутри образовательной дисциплины, так и в системе дисциплин, объединенных межпредметными связями [1, с. 7].

Метаметодический подход, на современном этапе, применяется в методике интегративных дисциплин культурологического содержания начального и общего образования. Элементы данного подхода описаны еще Д. Б. Кабалевским, подразумевающим взаимосвязь музыки, живописи и литературы [4]. 
Как показывает анализ научно-педагогической и методической литературы объективная сторона интеграции находит свое отражение непосредственно в содержании образования и способствует определению подхода к отбору и расположению учебного материала взаимосвязанных дисциплин таким образом, чтобы полученные знания в одной или нескольких областях, могли применяться и закрепляться при изучении других. Таким образом, интеграция образовательного процесса на основе синтеза искусств является важным условием по решению задач гражданско-патриотического воспитания. Специально организованный интеграционный образовательный процесс, то есть процесс на основе метаметадического подхода, направленный на формирование гражданско-патриотического воспитания достаточно актуален.

Основы гражданственности и патриотизма закладываются в ходе жизненного процесса человека, который находится в поле определенной социокультурной среды. С самого своего рождения люди инстинктивно, незаметно и естественно к тому, что их окружает: среда, природа, быт и культура. На основе этого и формируются глубокие чувства патриотизма. В этот момент и возрастает сила воздействия синтеза искусства [5]. В процессе изобразительной деятельности положительного эффекта можно добиться при использовании музыкального сопровождения. И свою очередь перед прослушиванием музыкального произведения можно использовать литературный материал и произведения живописи.

В продолжение этой темы хочется отметить еще один аспект, над которым необходимо проводить работу. Это знакомство с историей своей страны, своего народа. Обучающиеся с большим интересом слушают рассказы о героях своей страны, о великих сражениях, мощи армии. Необходимо акцентировать внимание детей на том, что он должен гордиться историей своей страны, ее традициями, памятниками и знаменитыми людьми. И именно сила искусства оказывает в этом неоценимую роль. Готовясь к праздничному концерту, можно наблюдать, как меняется отношение обучающихся к данному вопросу, насколько проникновенно и торжественно звучат стихи и песни, какими выразительными становятся движения во время исполнения танца, как вообще меняется отношение участников данного процесса ко всему происходящему. Для решения задач гражданско-патриотического воспитания на основе метаметодического подхода, как форму организации образователь- 
ного процесса, целесообразно использовать проектную деятельность. Актуальность методики проектной деятельности подтверждается авторитетным мнением ученых [7]. В научных трудах отмечается, что метод проектов очень эффективен. Проектная деятельность - это дидактическое средство активизации познавательного и творческого развития ребенка и одновременно формирование его личностных качеств.

Одним из ярких примеров проектной деятельности может служить проект «Я помню! Я горжусь!». Целью данного проекта было формирование у обучающихся нравственно - патриотических основ, гражданской позиции, в процессе расширения знания о Великой Отечественной войне на основе метаметодического подхода. Задачи, решаемые в ходе реализации проекта, были разделены на три блока - обучающиеся, педагоги, родители.

Обучающиеся - расширение представлений дошкольников о празднике «День Победы»; поддержка творческой инициативы и поисковой деятельности; развитие эмоциональной сферы; воспитание чувства гордости за свою страну и уважения к ветеранам войны.

Педагоги - повышение профессионального уровня в области гражданско-патриотического воспитания на основе синтеза искусств; совершенствование навыка планирования проектной деятельности; взаимодействие с родителями обучающихся и педагогическое просвещение в вопросе формирования гражданско-патриотических чувств через синтез искусств на основе метаметодического подхода; повышение творческой активности.

Родители - привлечение родителей к передаче семейных ценностей и традиций; активное участие в совместной деятельности семьи и образовательной организации.

Реализация проекта осуществлялась в три этапа. На первом этапе была сформулирована цель и обозначены задачи проекта, происходило изучение научной и методической литературы, так произведен анализ развивающей среды. Практическая деятельность по реализации проекта была отнесена ко второму этапу. Здесь же осуществлялось планирование, сбор информации, подбор художественно и музыкального материала. К этому же этапу были соотнесены образовательные ситуации, культурно - досуговая деятельность, беседы, тематические встречи с ветеранами войны, консультации для родите- 
лей, создание развивающей среды (выставки художественной литературы, репродукции картин, семейных фотографий), а также совместное создание атрибутов к танцам. Третий этап включал презентацию проекта «Я помню! Я горжусь!» через проведение музыкально-литературной композиции «Этот день Победы!». Здесь же проходила организация мини-музея «Долгие версты войны».

Новизна проекта заключается в использовании потенциала синтеза искусства в контексте гражданско-патриотического воспитания обучающихся на основе метаметодического подхода. Актуальность проекта заключается в важности гражданско-патриотического воспитания средствами искусства на современном этапе.

Структура проекта состоит из интегрированных образовательных ситуаций, направленных на решение поставленных задач, которые осуществлялись в ходе образовательной и самостоятельной деятельности, в пространстве культурно-досуговой деятельности. В качестве примера приведем содержание одного из интеграционных блоков: чтение художественной литературы Л. Кассиль «Твои защитники» и рассматривание плаката И. Тоидзе «Родина мать»; рассказ педагога «Дети герои ВОВ» и рассматривание картины «Письма с фронта А. Лактионова; рассматривание картины «Триумф победившей Родины» М. Хвалько и слушание отрывка «Симфония № 7», Д. Шостаковича; рассматривание фото-альбома «Герои наших семей», слушание песен о войне и создание коллажа «Победа!».

Таким образом, использование метаметадичекского подхода в условиях проектной деятельности, создает полноценные условия для гражданско-патриотического воспитания в современной школе и имеет большой потенциал для дальнейшего исследования.

\section{Литература}

1. Афанасьева, А. Б. Метаметодика и ее реализация при освоении этнокультуры в начальной школе / А. Б. Афанасьева // Начальная школа. - № 12. - 2007. - С. 7-13.

2. Валицкая, А. П. Метаметодический подход: конфликт интерпретаций / А. П. Валицкая // Метаметодика как перспективное направление развития частных методик. - Санкт-Петерубрг, 2005.

3. Жукова, Г. Е. Роль искусства в нравственно-патриотическом воспитании на этапе дошкольной ступени образования / Г. Е. Жукова, 
В. Н. Суворова // Материалы Всероссийской научно-практической конференции «Рисуем Победу-2019». - Москва, 2019. - 102 с.

4. Кабалевский, Д. Б. Как рассказывать детям о музыке? / Д. Б. Кабалевский. - Москва : Советский композитор, 1982. - 214 с.

5. Куланина, И. Н. Интеграция предметов эстетического цикла как средство развития творческого воображения младших школьников : монография / И. Н. Куланина. - Москва, 2008. - 228 с.

6. Титова, И. М. Метаметодический подход к модернизации обучения в общеобразовательной школе / И. М. Титова // Академические чтения. - Санкт-Петербург, 2002. - Выпуск 3. - 92 с.

7. Шкель, В.Ф. Метод проектов в образовательном процессе : учебно-методическое пособие / В. Ф. Шкель. - Саратов, 2010. - 124 с. 
Зимина Л. Г., педагог дополнительного образования МУ ДО «Радуга» и МОУ СОШ № 13 КГО

\section{ГРАЖДАНСКО-ПАТРИОТИЧЕСКОЕ ВОСПИТАНИЕ ОБУЧАЮЩИХСЯ В МУ ДО «РАДУГА» КГО ЧЕЛЯБИНСКОЙ ОБЛАСТИ}

Аннотация. В данной статье рассматривается вопрос организации нравственно-эстетического воспитания на практическом примере создания и реализации авторской целевой программы по гражданскому и патриотическому воспитанию обучающихся «Воспитать гражданина России».

Ключевые слова: гражданско-патриотическое воспитание, проектная деятельность, патриотизм.

Zimina L. G.

teacher of additional education of MU DO "Raduga" and MOE SOSH No. 13 KGO

\section{CIVIL AND PATRIOTIC EDUCATION OF STUDENTS IN THE MU DO “RAINBOW" KGO CHELYABINSK REGION}

Abstract. This article examines the issue of the organization of moral and aesthetic education on the practical example of the creation and implementation of the author's target program for civil and patriotic education of students "To educate a citizen of Russia". Keywords: civil and patriotic education, project activity, patriotism.

Key words: civil and patriotic education, project activity, metametodics.

В последние годы российская образовательная система претерпела значительные изменения. Перемены затронули различные сферы образовательной деятельности. Экономическая нестабильность в стране, размывание нравственных и этических ценностей, резкое снижение социальной активности молодежи, кризис семьи и отношений между родителями и детьми заставляют по-новому взглянуть на образовательную систему и возможности воспитания [2]. 
Сегодня для России нет более важной идеи, чем патриотизм. Считаем, что для того, чтобы стать патриотом, не обязательно быть героем, достаточно любить свою Родину такой, какая она есть, ведь другой не будет. Патриотизм - это прежде всего состояние духа, души. Жизнь показывает, что дети растут, и приходит время, когда они спрашивают о семейной чести, о патриотических делах родителей, дедушек и бабушек, размышляя над прошлым своей Родины. Это хорошие уроки мужества для подрастающего поколения. Ведь в настоящее время эта проблема очень актуальна [1, с. 26-27].

В условиях становления гражданского общества и правового государства необходимо осуществлять воспитание принципиально нового, демократического типа личности, способной к инновациям, к укреплению собственной жизнью и деятельностью, делами общества, готовой рассчитывать на собственные силы, собственным трудом обеспечивать свою материальную независимость [3]. В формирование такой гражданской личности, сочетающей в себе развитую нравственную, правовую и политическую культуру, в процессе воспитания активно включаются учреждения дополнительного образования детей [4, с. 16]. В статье № 2 Закона РФ «Об образовании» определены требования к воспитательной деятельности в государственных и муниципальных образовательных учреждениях.

Среди важнейших названа задача патриотической направленности: «Воспитание гражданственности, трудолюбия, уважения к правам и свободам человека, любви к окружающей природе, Родине, семье».

В муниципальном учреждении дополнительного образования «Радуга» создана целевая программа по гражданскому и патриотическому воспитанию обучающихся «Воспитать гражданина России». Программа направлена на воспитание патриотизма и формирование гражданственности, представляет собой определенную систему содержания, форм, методов и приемов педагогического воздействия.

Педагоги нашего учреждения способствуют формированию активной жизненной позиции обучающихся, развивают умения и навыки конструктивно-критического мышления, самостоятельности, воспитывают уважение к народным традициям и культуре, помогают понимать принципы и ценности демократического гражданского общества, жизни и деятельности человека в обществе. Одним из направлений реализации программы является участие обучающихся, педагогов и ро- 
дителей в патриотических акциях и мероприятиях, посвященных празднованию Дня Победы советского народа в Великой Отечественной войне. Среди акций особое значение уделяют участию во всероссийской детско-юношеской патриотической акции «Рисуем Победу» [6]. Ребята проявляют большой интерес, желание, творчество в подготовке к такой значимой акции, ценят героическое прошлое своей Родины.

Хочется отметить сотрудников детской библиотеки № 8 поселка Горняк КГО Челябинской области, педагогов МОУ СОШ № 13 и МОУ школы-интерната № 8 Копейского городского округа, которые оказывают всестороннюю помощь МУ ДО «Радуга» в реализации программы «Воспитать гражданина России». Важно сохранить на века и передавать из поколения в поколение память о Великой Отечественной войне, о трагических событиях и героических поступках наших предков [7, c. 82]. Воспитывать уважение к ветеранам, участникам Великой отечественной войны и национальной гордости за страну.

\section{Литература}

1. Головачев, В. С. Всероссийская акция «Рисуем Победу» : методические рекомендации / В. С. Головачев, А. И. Аршинова // Чебоксары : Плакат, 2019. - 60 с.

2. Головачев, В. С. Нравственно-патриотическое воспитание детей младшего возраста в условиях межведомственного взаимодействия (из опыта проведения Всероссийской акции «Рисуем Победу») / В. С. Головачев // Сборник трудов участников Всероссийской научно-практической конференции «Рисуем Победу-2019». - Москва, 2019. - С. 26-32.

3. Головачев, В. С. Опыт сетевого взаимодействия учреждений образования и культуры в нравственно-патриотическом воспитании дошкольников / В. С. Головачев // Духовно-нравственное и патриотическое воспитание молодежи: материалы Всероссийской дистанционной научно-практической конференции. - Чебоксары : Плакат, 2020. - С. 74-79.

4. Демидов, А. А. Сетевая модель центров этико-правового образования и гражданско-патриотического воспитания и центров медиаобразования на базе школьных библиотек: необходимость создания, возможности и реальные перспективы / А. А. Демидов, А. Л. Третьяков // Медиаобразование. - 2016. - № 3. - С. 16-22.

5. Третьяков, А. Л. Формирование межведомственной и межсекторной модели развития гражданского, патриотического и этико-право- 
вого образования и воспитания молодежи в формате социального проекта «Центр гражданской, этико-правовой и иной социально значимой информации памяти профессора Н. И. Элиасберг» / А. Л. Третьяков, А. А. Демидов // От науки к бизнесу. Трансфер технологий - новое измерение. - Санкт-Петербург, 2015. - С. 136-139.

6. Рисуем Победу [Электронный ресурс]. - URL: http://risuempobedu.ru (дата обращения : 02.07.2021).

7. Скрынник, М. А. Воспитание нового патриота / М. А. Скрынник // Нравственно-эстетическое и гражданско-патриотическое воспитание в государственных учреждениях образования и культуры. - Москва, 2019. C. 82-86. 
Третьяков А. Л.,

доцент кафедры дошкольного образования Московского государственного областного университета, старший преподаватель кафедры социальной психологии Московского психолого-социального университета

\section{ПРОЕКТНАЯ ДЕЯТЕЛЬНОСТЬ В ЭКОЛОГИЧЕСКОМ ОБРАЗОВАНИИ СТАРШИХ ДОШКОЛЬНИКОВ}

Аннотация. В статье выявлены тенденции развития проектной деятельности как эффективной технологии экологического образования на дошкольном образовательном уровне. Приведена история вопроса и возможные варианты развития в современной дошкольной организации.

Ключевые слова: экологическое образование, дети старшего дошкольного возраста, ФГОС ДО, проектная деятельность, формирование.

Tretyakov A. L., Associate Professor at the Department of Preschool Education Moscow Region State University, Senior Lecturer at the Department of Social Psychology Moscow Psychological and Social University

\section{PROJECT ACTIVITIES IN ENVIRONMENTAL EDUCATION OF SENIOR PRESCHOOLERS}

Abstract. The article identifies trends in the development of project activities as an effective technology for environmental education at the preschool educational level. The history of the issue and possible options for development in a modern preschool organization are given.

Key words: environmental education, children of senior preschool age, FSES DO, project activities, formation.

Воспитание экологической культуры, как сложного личностного образования, осуществляется постепенно в деятельности, которая имеет практическую направленность. Мы полагаем, что такой деятельностью, которая обеспечивает возможности получения, синтеза, комбинирования и активного применения информации, является метод проектов, так как данный метод позволяет целостно и системно 
учитывать разнообразные аспекты экологического образования дошкольников не только на уровне организационных условий, но и на уровне осуществления творческой деятельности.

На современном этапе развития ДОО одно из средств, которое усиливает развивающий эффект образовательной программы, а также оказывает положительное влияние на формирование личности дошкольника, является метод проектов, который можно рассматривать как самостоятельную структурную единицу воспитательного процесса, что отражено в результатах современных исследований [1-10].

Согласно мнению Н. В. Матяш, метод проектов - это совокупность определенных действий, предварительной работы, замысла, с целью создания реального предмета, объекта либо теоретического и творческого продукта. Результат проектного метода - это творческая деятельность.

Современные педагогические проблемы часто решаются за счет создания и введения в процесс воспитания и образования процесса инновационных систем, что требует тщательного проектирования, которое выражается не только в предварительном планировании изменений, но и в предсказании последствий их влияния на здоровье и жизнь детей. Данное обстоятельство выводит проблему проектов на одно из первых мест в практике и теории деятельности педагога.

Важно внедрять новые технологии с целью достижения результата образования, где метод проектов является системообразующим подходом, усиливающий эффекты программы образования, оказывая положительное воздействие на личностное развитие ребенка. Образование с применением проектного метода, по мнению Н. В. Гузенко, Н. В. Черненко, О. Н. Хижняковой, является путем формирования проективных способов взаимодействия с миром.

Важно, в рамках данного исследования, проанализировать работы, показывающие суть проектной деятельности, место в процессе воспитательной работы ДОО, проблемный характер. Совместной познавательной творческой деятельностью детей является проектная деятельность, имеющая общую цель, пути деятельности и согласованными методами, которые несут в себе один результат, то есть создать проект. Заранее проработанные представления по конечному продукту - это условие проектной деятельности.

Мы заметили, что на недостаточном уровне представлен потенциал проектного метода в экологическом образовании детей, хотя проекты могу не только развивать творческие и познавательные способности, но 
и повышать мотивацию, развивать личность, оказывать влияние на развитие экологической культуры.

Научной разработкой применения метода проектов занимался американский педагог и философ Дж. Дьюи, а также его ученик и последователь В. Х. Килпатрик. Теоретическая база метода проектов - это прагматическая педагогика Дж. Дьюи, который утверждал, что основной результат обучения - это формирование мышления ребенка, которое основывается на личном опыте, поэтому автором была разработана теория формирования личности, приспособленной к жизни.

Последователь Дж. Дьюи, В. Х. Килпатрик, развивал новаторские идеи своего учителя касательно организации определенной целенаправленной практической деятельности детей на самостоятельной основе. Он считал, что образовательный процесс в рамках ДОУ должен быть основан на ряде опытов, которые связаны так, чтобы знания, которые приобретают дошкольники в результате одного опыта, служили развитием и обогащением последующих. Поэтому, обучение должно осуществляться через процессы организации целевого акта, который включает в себя: постановку проблемы, составление реализационного плана с оценкой его выполнения. Применение таких условий в рамках ДОУ помогает организовать жизнь ребенка в будущем. В дальнейшем идеи американских педагогов развивали А. Флекснер и Э. Коллингс.

В России идеи метода проектов связаны с именем П. Ф. Каптерева, который в своей книге «Дидактические очерки» (цит. по: Г. В. Абуляшевой) писал: «Ум выше знаний, так как, овладевая умом, всегда можно получить знания, а владея знаниями, не всегда можно приобрести ум. Знание само по своей сути, вне отношения к развитию ума, имеет в образовании очень мало значения, так как всего не узнаешь, и всем наукам не обучишься, поэтому самое важное в приобретении учащихся - это умение правильно мыслить, говорить и учиться». Позже, метод проектов развивался параллельно с разработками американских ученых и таких отечественных педагогов, как Н. К. Крупской, П. П. Блонского, В. В. Игнатьева, В. Н. Шульгина и др., как отмечает в своем исследовании Г. В. Алябушева. Данные авторы считали, что проектная деятельность может обеспечить развитие познавательной активности, самостоятельности и творческой инициативы ребенка.

Согласно мнению Г. В. Алябушевой, которая провела анализ положительных и отрицательных сторон применения метода проектов в ор- 
ганизации процессов обучения, можно выделить недостатки и достоинства данного процесса, а именно к положительным сторонам автор отнесла реализацию возможностей преемственности, развития коммуникации за счет публичного выступления, применение дифференцированного и индивидуального подхода, развитие восприятия к критике и анализа других проектов.

Среди отрицательных сторон автор назвала отсутствие планирования, учебных материалов.

На современном этапе проблематикой применения метода проектов занимаются М. Л. Сердюк, Н. М. Матяш. Их исследования показывают, что метод проектов наиболее полно может проявить позитивные характеристики в среде образования, так как обучение методом проектов развивает формирование проектного способа взаимодействия с миром не только в нормативных ситуациях, но и в пространстве возможностей.

Проектная деятельность по мнению Н. В. Матяш является формой познавательной и учебной активности детей дошкольного возраста, направленная на достижение поставленных целей по созданию процесса творчества, обеспечения единства разных стороны воспитания, преемственности школы и ДОО. Проектная деятельность как совместная познавательная и творческая деятельность по мнению П. А. Маслова, направлена на овладение дошкольниками приемами достижения задач самостоятельно, а с точки зрения М. В. Чановой технологией проблемного обучения можно назвать метод проектов, что оказывает влияние на развитие творческой, активной и самостоятельности личности, которая старается создать собственный продукт.

Мы полагаем, что проектный метод основывается на понимании дошкольников важности в личностном развитии, учитывает возможности, творчество, эмоции, самостоятельность.

Анализ педагогической практики и теории позволяет отметить, что современные педагоги грамотно оценивают суть метода проектов, определяя его как совместную учебно-познавательную, научно-исследовательскую и творческую деятельность педагога и воспитанника, которая обладает общей целью, согласованными способами и методами деятельности, направленных на достижение результата - создание проекта. Также, данные авторы рассматривали метод проектов, как эффективное средство формирования познавательной активности дошкольника.

Метод проектов вызывает у детей дошкольного возраста интерес 
к познанию, способствуя личностному росту и формирует познавательную активность, так как выполнение проекта создает ситуации решения нескольких задач и от ребенка требуется навык координирования собственных усилий и усилий других людей. Для того, чтобы ребенку добиться успеха, важно активно искать информацию, добывать новые знания.

Как отмечает Н. В. Иванова, метод проектов способствует широкому развитию у детей исследовательских качеств, а также вносит разнообразие в саморазвитие и развитие ребенка, поэтому суть проектной деятельности заключается в том, что она помогает связывать обучение и жизнь ребенка, формируя познавательную активность и интерес, развивает самостоятельность, творчество и навыки коллективного сотрудничества, поэтому может применяться в экологическом образовании.

Еще одна существенная отличительная черта проектной деятельности заключается в том, что она вынашивает адресный характер, как в ходе общения, так и в итоге. Как полагает Н. Е. Веракса, проектная деятельность обладает ярко выраженной окраской и в конечном результате становится одним из немногих общественно значимых действий, которые доступны дошкольнику.

Проекты могут иметь разнообразную тематику, и в ходе их осуществления одновременно и параллельно находят решение креативные, образовательные, психологические и воспитательные задачи.

Имеется классификация проектов по Е. С. Евдокимовой:

1. По методу, который доминирует в проекте: экспериментальный, информационный, креативный, игровой, приключенческий, практикоориентированный.

2. По характеру содержания проекта: ребенок и его семья, ребенок и природа, ребенок и рукотворный мир, ребенок, социум и его культурные ценности.

3. По характеру участия ребенка в проектировании: заказчик проекта, эксперт, исполнитель проекта, участник проекта.

4. По характеру контактов: внутри одной возрастной группы, в контакте с иной возрастной группой, внутри дошкольного учреждения, открытый, в контакте с семьей, учреждениями культуры, общественными организациями.

5. По числу участников проекта: персональный, парный, групповой, фронтальный.

6. По длительности осуществления проекта: кратковременный, 
средней продолжительности, долговременный, информационный.

Н. Е. Веракса выделяет три главных вида проектной деятельности: креативный, исследовательский и нормативный; каждый из них обладает собственными отличительными чертами, структурой и характерными стадиями осуществления.

В детских садах зачастую планируются и организуются исследовательские и креативные проекты, которые направлены на формирование познавательных и коммуникативных способностей дошкольников. Проектная деятельность содействует, кроме того, становлению различной игровой деятельности, формированию и укреплению дружеского взаимодействия между детьми. Педагоги дошкольных учреждений понимают, что замысел дошкольника опережает его способности и ребенку требуется помощь взрослого, по этой причине к осуществлению проектной деятельности привлекаются родители.

Наиболее существенным является доминирующий вид деятельности. В практике ДОО используются следующие типы проектов:

- исследовательски-творческие: осуществляется исследовательский поиск, результаты которого оформляются в виде какого-либо творческого продукта (газеты, драматизации, картотеки опытов, детского дизайна, кулинарной книги и пр.);

- ролево-игровые: это проект с элементами творческих игр, когда дети входят в образ персонажей сказки и по-своему решают поставленные проблемы;

- информационно-практико-ориентированные: дети собирают информацию о каком-то объекте, явлении из разных источников, а затем реализуют ее, ориентируясь на социальные интересы: оформление дизайна группы, квартиры, и т. п.;

- творческие: как правило, не имеют детально проработанной структуры совместной деятельности участников. Результаты оформляются в виде детского праздника, выставки, дизайна и рубрик газеты, альбома, альманаха.

Другими признаками классификации являются:

- состав участников (групповой, подгрупповой, личный, семейный, парный и пр.);

- продолжительность (краткосрочный - несколько занятий, однадве недели, средней продолжительности - один-три месяца, долгосрочный - до одного года). 
В рамках экологического образования, работа над проектами обладает огромным значением для развития познавательного развития ребенка, так как через объединение разнообразных областей знаний происходит формирование целостного видения картины окружающего мира. Совместная работа дошкольников наделяет их способностью проявить себя в разнообразных видах деятельности.

Так как метод проектов - это система постепенно усложняющихся практических заданий, то за счет этого осуществляется непрерывная перестройка опыта ребенка, углубление его экологических знаний, совершенствование практических умений и навыков, а также происходит личностное развитие в таких направлениях, как: инициативность, самостоятельность, любознательность.

Педагог заранее тщательно продумывает и предварительно планирует проектную деятельность. Педагог при планировании проекта определяет тему и подбирает материалы, а также подсказывает пути реализации проектной деятельности для детей: у кого просить помощи, какие материалы использовать, как оформить продукт. Чем старше дети, тем большую самостоятельность им предоставляют на этапе целеполагания проектной деятельности. При этом дети сами могут предложить проблемы проектов, например: исследование на тему «Почему тают ледники?», «Микропластик, что за беда?», «Проблема глобального потепления», либо это могут быть фотопроекты «Загрязнение моего города», организация акций «Раздельный сбор мусора», либо создание специальных корзин для сортировки отходов, также это могут быть природные проекты: «Создание кормушек», «Животные моего края», «Природные особенности моего города» и так далее.

Особенности использования метода проектов в экологическом образовании старших дошкольников заключаются в создании определенных педагогических условий:

1. Первое условие - повышение познавательного интереса детей к объектам и явлениям природы. Метод проектов позволяет развивать познавательный интерес к различным областям экологических представлений.

2. Второе условие - побуждение детей к активному участию в реализации экологических проектов. Проект, который исполняют дети, должен вызывать у них энтузиазм, увлекать, идти от сердца. Тогда будет осознаваться необходимость экологических представлений, и они будут лучше усваиваться. 
3. Третье условие - это использование интеграции образовательных областей на основе единого экологического проекта.

В дошкольном образовании метод проектов рассматривается как один из вариантов интеграции (интеграция образовательных областей на основе единого проекта), что соответствует ФГОС дошкольного образования. Наблюдения, опыты и практическая деятельность способствуют накоплению у детей конкретно-образных представлений об окружающей действительности, фактических знаний, которые являются материалом для последующего их осознания, обобщения, приведения в систему. В результате дети начинают понимать, что объекты и явления взаимосвязаны и представляют собой единое целое, окружающий мир не является чем - то статичным, он постоянно изменяется. Выбранная тема экологического проекта «проецируется» на все образовательные области ФГОС, и на все структурные единицы образовательного процесса, через различные виды детской деятельности. Таким образом, получается целостный, а не разбитый на части образовательный процесс.

Основным организатором детской продуктивной деятельности, источником информации, консультантом и экспертом является воспитатель. Он основной руководитель проекта и последующей исследовательской, игровой, художественной, практико-ориентированной деятельности, координатор индивидуальных и групповых усилий детей в решении проблемы. При этом взрослый выступает партнером ребенка и помощником в его саморазвитии.

\section{Литература}

1. Бахтина, Е. В. Межкультурный диалог в библиотеке / Е. В. Бахтина, Ю. Ф. Андреева, В. В. Орлов // Библиопанорама. - 2017. - № 1. - С. 32-34.

2. Брянцева, М. В. Альтернативные формы противодействия антисоциальным проявлениям молодежных субкультур / М. В. Брянцева // Самоидентификация молодежи в социальном пространстве. - Москва, 2009. - C. $68-78$.

3. Головачев, В. С. Возможности межрегионального проектного взаимодействия учреждений образования и культуры в нравственно-эстетическом воспитании дошкольников / В. С. Головачев // Вестник Чувашского государственного педагогического университета им. И. Я. Яковлева. - 2019. - № 5. - С. 143-150. 
4. Головачев, В. С. Новые формы взаимодействия учреждений образований и культуры на основе культурно-образовательных интернетплатформ / В. С. Головачев // Архитектура университетского образования: построение единого пространства знаний. - Санкт-Петербург, 2020. - С. 354-361.

5. Емельяненкова, А. В. Индивидуально-психологические особенности руководителя как фактор творческого потенциала / А. В. Емельяненкова, О. В. Кобелева // Проблема творческого развития личности в XXI веке. - Ульяновск, 2004. - С. 240-241.

6. Колесникова, М. Н. Архитектура и дизайн библиотек : учебное пособие / М. Н. Колесникова, Е. В. Бахтина. - Санкт-Петербург, 2016. -128 c.

7. Коренева, Ю. В. Литературные экскурсии музеев как вид образовательного туризма // Наука на благо человечества - 2018 / Ю. В. Коренева, К. С. Хосровян, О. В. Кобелева. - Москва, 2018. - С. 202-206.

8. Семенов, К. Б. Инклюзивный образовательный процесс и нравственные ценности / К. Б. Семенов, А. С. Семенова // Право и образование. -2020 . - № 8. - С. 35-41.

9. Семенов, К. Б. Этиология понятия «здоровье» в педагогической теории / К. Б. Семенов, Л. М. Борлакова // Современный ученый. - 2017. № 1. - С. 200-202.

10. Dyachenko I. L. The estimation of possibilities of product and imported raw substitution / I. L. Dyachenko, V. Sh. Khetagurova, G. A. Bryukhanova, M. N. Sosnov, M. V. Brantseva // Biosciences Biotechnology Research Asia. - 2015. - Volume 12. - № 2. - P. 1603-1613. 
Кудрявцева К. Л.,

библиотекарь второй категории детской библиотеки № 207 имени В. В. Бианки ГБУК г. Москвы «ЦБС ЗАО», член организационного комитета детско-юношеской акции «Рисуем Победу»

\title{
ВОСПИТАНИЕ ГРАЖДАНСТВЕННОСТИ И ДУХОВНО-НРАВСТВЕННОГО НАСЛЕДИЯ ЧЕРЕЗ ОСОЗНАННОЕ ВОСПРИЯТИЕ ИСТОРИЧЕСКОГО НАСЛЕДИЯ
}

\begin{abstract}
Аннотация. Данная статья раскрывает важность и ценность акции «Рисуем Победу» в современных образовательных реалиях, ценность патриотического воспитания детей школьно-дошкольного возраста на основе потенциала детской публичной библиотеки. Раскрывается процесс координационной работы проекта и его реализация. Статья описывает важность творческой деятельности и процесса осмысления событий войны и подвигах предков.
\end{abstract}

Ключевые слова: акция, культура, патриотизм, День Победы, библиотека, подвиг, народ, Родина.

Kudryavtseva K. L.,

librarian of the 2nd category of the children's library No. 207 named after V. V. Bianchi GBUK of Moscow "CBS CJSC", member of the organizing committee of the children's and youth action "Draw a Victory"

\section{EDUCATION OF CITIZENSHIP AND SPIRITUAL AND MORAL HERITAGE THROUGH THE CONSCIOUS PERCEPTION OF HISTORICAL HERITAGE}

Abstract. This article reveals the importance and value of the Action "Draw a Victory" in modern educational realities, the value of patriotic education of children of school and preschool age based on the potential of the children's public library. The process of coordination work of the project and its implementation is revealed. The article describes the importance of creative activity and the process of understanding the events of the Great Patriotic War and the exploits of their ancestors.

Key words: action, culture, patriotism, Victory Day, library, feat, people, motherland. 
В настоящее время патриотическим воспитанием детско-юношеской аудитории занимаются не только образовательные учреждения, но и учреждения сферы культуры. В театрах показывают спектакли на военную тематику, снимаются кино о событиях военных лет. А также множество художественных выставок о событиях Великой Отечественной войны демонстрируются самым широким слоям общества [2].

Разностороннее обогащение личности закладывает ценностную основу для фундаментального ориентира человека. Государство содействует и старается обогащать и расширять ценностную культуру своего народа, чтобы каждый осознавал и помнил свою историю, знал о подвигах предков, с благодарностью относился к людям защищавших нашу страну, чтобы мы могли жить в мирное время [4, с. 39].

Патриотическое воспитание личности идет рядом с духовно-нравственным воспитанием. Таким направлением занимаются не только в образовательных и досуговых организациях, но и в местах культурного просвещения.

Современные библиотеки стали не только местом, где человек знакомиться с литературой, но и культурно-образовательным центром. Ведение проектов, проведение мероприятий, обогащает и насыщает работу библиотек. Нынешнего школьника не так-то просто заинтересовать книгой, но с интересной подачей, с возможностью проявить себя, узнать что-то новое, ребенок с удовольствием захочет принять участие в предлагаемых конкурсах, проектах и акциях [3, с. 17-18].

Проектная деятельность становится все более распространенным способом, с помощью которого возможно решать не только образовательные, развивающие, но и воспитательные задачи. В данном формате ребенок способен раскрыть потенциал, сформировать новую социальную-гражданскую позицию и стать частью проекта, приобретая новые знания.

Акция «Рисуем Победу» ставит перед собой задачу расширять знания детей и транслировать значимость происходящих событий военных лет, раскрывая общественную значимость праздника Дня Победы. Формирование у подрастающего поколения чувства гражданственности, любви к Родине и гордости за свой народ, является фундаментом становления гражданина и патриота своей страны [1].

Данная акция имеет многолетний опыт. С каждым годом количество участников только растет. В 2021 г. количество участников стало рекордным: 531779 участников. 
Акция «Рисуем Победу» объединила участников из разных регионов России и других соседних государств. В текущем 2021 г. автор настоящей статьи являлась координатором акции по г. Москве. 18337 детей приняли участие в акции и создали уникальные и творческие работы [5]. Мною активно велась работа по распространению информации о данной акции, рассылались приглашения для привлечения новых участников. В социальных сетях осуществлялась информирование. Ежедневно поступали запросы о помощи загрузке работ. Поступали звонки, письма на почту и в социальных сетях. Координаторы всегда оперативно оказывали помощь и разъясняли последовательность действий.

По завершению акции приходило много слов благодарности. Данный проект несет огромную ценность и важную миссию. Ведь война 19411941 гг. унесла множество жизней и помня о героях нашей Родины мы создаем новое прекрасное будущее. Благодаря просветительской работе в семьях, садах, школах, дети понимают важность Дня Победы и гордятся подвигами предков. В школах проводились классные часы, в детских садах просветительские мероприятия, а в семьях велись беседы, в которых мамы рассказывали детям о своих бабушках и дедушках. Это помогает не только вспомнить, но и узнать новое об истории своей страны.

Через творческую деятельность, акция «Рисуем Победу» формирует и поддерживает стремление подрастающего поколения познакомиться с историей страны, осмысливая происходящее. Подвиги предков вдохновляют, и отставляют свой отпечаток на жизни народа [6]. После погружения в атмосферу тех лет, все больше людей начинают ценить жизнь, совершать больше поступков на благо общества, помогать ближнему. Это одна из важнейших ценностей, которая тонкой нитью пронизывает весь проект «Рисуем Победу», оставляя свой след в каждом.

В библиотеке № 207 им. В. В. Бианки я являюсь руководителем кружка «Мастерская творчества». В рамках кружковой деятельности в преддверии Дня Победы проводились тематические мероприятия, ребята узнавали новое о войне, а также создавались творческие работы, которые ребята загружали на сайт. В стенах библиотеки была организована выставка художественных работ.

Церемония награждения и телемост стали итогом проведения акции. В библиотеку были приглашены и награждены участники акции. Ребята увидели прекрасный концерт и сохраняя традиции, мы возлагали цветы на монумент Московско-минской дивизии. 
Таким образом, патриотическое воспитание является непрерывным неисчерпаемым процессом, который закладывает свою основу для формирования личности, уважающей свой народ, свою страну и национальную историю. Важно не только наглядно демонстрировать и знакомить детей с событиями военных лет, но и помочь осознать. Ведь только тогда ребенок по истине погрузиться и всецело ощутит славную историю Великой Победы, переставая воспринимать это день как дань традиции, помогая выстроить поступки в настоящем и творить лучшее будущее.

\section{Литература}

1. Головачев, В. С. Всероссийская акция «Рисуем Победу»: методические рекомендации / В. С. Головачев, А. И. Аршинова. - Чебоксары : Плакат, 2019. - 60 с.

2. Головачев, В. С. Нравственно-патриотическое воспитание детей младшего возраста в условиях межведомственного взаимодействия (из опыта проведения Всероссийской акции «Рисуем Победу») / В. С. Головачев // Сборник трудов участников Всероссийской научно-практической конференции «Рисуем Победу-2019». - 2019. - С. 26-32.

3. Демидов, А. А. Сетевая модель центров этико-правового образования и гражданско-патриотического воспитания и центров медиаобразования на базе школьных библиотек: необходимость создания, возможности и реальные перспективы / А. А. Демидов, А. Л. Третьяков // Медиаобразование. - 2016. - № 3. - С. 16-22.

4. Третьяков, А. Л. Гражданско-патриотическое и этико-правовое просвещение обучающихся в современной школьной библиотеке: некоторые подходы к теоретическому осмыслению проблемы / А. Л. Третьяков // Вестник Саратовского областного института развития образования. - 2017. - № 1. - С. 38-43.

5. Рисуем Победу [Электронный ресурс]. - URL : http://risuempobedu.ru/ (дата обращения : 02.07.2021).

6. Скрынник, М. А. Воспитание нового патриота / М. А. Скрынник // Нравственно-эстетическое и гражданско-патриотическое воспитание в государственных учреждениях образования и культуры. -2019. - С. 82-86. 
Цыпкина У. А., воспитатель ГБОУ «Школа № 922» г. Москва

Демиенко Е. П., воспитатель ГБОУ «Школа № 922» г. Москва

\section{РАСТИМ ДЕТЕЙ ПАТРИОТАМИ}

Аннотация. В статье рассматривается проблематика оптимальной организации нравственно-патриотического воспитания детей на базе образовательного комплекса. Приводится пример работы воспитателей по подготовке участников Всероссийской детско-юношеской акции «Рисуем Победу».

Ключевые слова: патриот, гражданско-патриотическое воспитание, патриотизм, воспитатель, рисунок, проект.

Tsypkina U. A., teacher of GBOU “School No. 922” Moscow

Demchenko E. P., educator of GBOU "School No. 922" Moscow

\section{WE RAISE OUR CHILDREN AS PATRIOTS}

Abstract. The article considers the problems of optimal organization of moral and patriotic education of children on the basis of an educational complex. An example of the work of educators on the preparation of participants of the All-Russian children's and youth action "Draw a Victory" is given.

Keywords: patriot, civil-patriotic education, patriotism, educator, drawing, project.

«Заботливый садовник укрепляет корень, от мощности которого зависит жсизнь растения на протяжении нескольких десятилетий. Так воспитатель должен заботиться о воспитании у своих детей чувства безграничной любви к Родине».

(В. А. Сухомлинский).

«Мам, а что такое войнушка?»

...Так, понятно, что увлечение старшего брата военной стратегией, не прошло мимо внимания сестры: яркая картинка на мониторе, звуковые эффекты и обсуждение с приятелями тактики ведения боя сделали свое дело. 
Война... Сколько сказано и написано о разных войнах, разобраны они со всех точек зрения взрослыми. А как объяснить четырехлетнему ребенку, девочке, из благополучной семьи, не знающей (к счастью) иных бед, кроме порванных колготок и разбитой чашки, что строй смешных фигурок в мониторе в реальности никогда не поднимется после точной пулеметной очереди, а красиво расцветший красным огоньком танк, станет причиной горькой вести родным!

Сложность заключается в том, что ребенок четырех лет только начинает осваивать абстрактные понятия «жизнь» и «смерть». И очень важно, чтобы психика ребенка восприняла эти новые знания правильно.

Сейчас стало больше внимания уделяться духовно-нравственному воспитанию детей, лежащему в основе патриотизма. Но не следует думать, что развитие патриотизма - это только военно-патриотическое или даже политизированное воспитание детей. Прививать патриотизм следует, соизмеряя усилия и используемые приемы с возрастом детей, с их естественными стремлениями, постепенно раскрывая и усложняя, детализируя вводимые понятия [2]. Чтобы подготовить детей, дать им нужные знания, был разработан долгосрочный проект «Моя Родина», который включил в себя различные формы работы, как с детьми, так и с родителями: беседы, экскурсии, просмотр видеороликов и презентаций, чтение художественной литературы, изучение картин, плакатов, консультации для родителей и художественно-творческую деятельность [4]. В рамках проекта был проведен конкурс чтецов. Дети прочитали стихи С. Михалкова «Нет войны», А. Барто «В дни войны», О. Масловой «Спасибо героям», А. Усачева «Что такое День Победы».

В группе была организована выставка, посвященная Дню Победы «Чтобы помнили». В нее вошли произведения о войне, которые можно читать детям-дошкольникам: С. Алексеев «Рассказы о Великой Отечественной войне», С. Георгиевская «Галина мама», Ю.Герман «Вот как это было», Г. Черкашин «Кукла».

Также были использованы плакаты и художественные иллюстрации, картины А. Михайлов «Горький хлеб», П. Широков «За родину», А. Дейнека «Матросы», Б. Щербаков «Зло мира», А. Лактионов «Письмо с фронта», К. Антонов «Победители».

В группе стали часто звучать музыка и песни военных лет и о войне «День Победы», «Катюша», «Пусть о войне не знают дети», «В лесу прифронтовом», «Мы не хотим войны». 
На заключительном этапе проекта с детьми был проведен групповой конкурс «Рисуем войну». А потом П. Александрова захотела нарисовать свой рисунок и принять участие во Всероссийской детско-юношеской акции «Рисуем Победу» [1]. Педагогами и родителями был внимательно изучен сайт акции [3], произошло знакомство с основными документами, приложенными к заявке: положением о проведении акции, методическими рекомендациями, рекомендованной литературой и электронными источниками. Размещенная на сайте акции информация помогла подготовиться к занятию с детьми и способствовала более полному и многогранному представлению военной темы для детской аудитории.

Работа с Полиной в этом направлении началась с общения с семьей, с определения круга тем и вопросов, которые можно обсудить с ребенком дома и в детском саду. Учитывая небольшой возраст девочки, решили, что стоит избегать длительных рассказов и ненужных подробностей.

Рассматривали различные иллюстрации и фотографии о войне, Дне Победы, доступные пониманию ребенка. Объясняли, что и почему на них изображено. Слушали песни военных лет и о войне, читали стихи, например: Е. Благинина «Почему ты шинель бережешь?».

Дома родители рассказывали о том, как воевали ее прадедушки и прабабушки, ходили в Измайловский парк, чтобы поздравить с Днем Победы ветеранов. Атрибутика (Георгиевские ленты, флаги, плакаты) тоже помогали Полине, создавала ощущение сопричастности к празднику.

Рисунок получился необычным. Казалось бы, главный герой картины, воин, стоит спиной к зрителю. В центре внимания оказались глаза ребенка, обнимающего вернувшегося солдата, неважно отца ли, деда, брата. Раненого, но выжившего! И пусть кругом еще разруха, но верится, что впереди - только хорошее! Хорошо, что существуют такие конкурсы, и неравнодушные внимательные родители и педагоги. Всем нам, большим и маленьким нужна Память!

\section{Литература}

1. Головачев, В. С. Всероссийская акция «Рисуем Победу» : методические рекомендации / В. С. Головачев, А. И. Аршинова // Чебоксары : Плакат, 2019. - 60 с.

2. Третьяков, А. Л. Гражданско-патриотическое и этико-правовое просвещение обучающихся в современной школьной библиотеке: не- 
которые подходы к теоретическому осмыслению проблемы / А. Л. Третьяков // Вестник Саратовского областного института развития образования. - 2017. - № 1. - С. 38-43.

3. Рисуем Победу [Электронный ресурс]. - URL : http://risuempobedu.ru/ (дата обращения : 02.07.2021).

4. Скрынник, М. А. Воспитание нового патриота / М. А. Скрынник // Нравственно-эстетическое и гражданско-патриотическое воспитание в государственных учреждениях образования и культуры. -2019. - С. 82-86. 
Бондарь О. А.,

заведующая отделом декоративно-прикладного и изобразительного искусства ГБОУДО «ДДЮТ» г. Севастополь

Митусова Ю. А., педагог дополнительного образования ГБОУДО «ДДЮТ» г. Севастополь

\section{ИЗ ОПЫТА ПОДГОТОВКИ УЧАСТНИКОВ ВСЕРОССИЙСКОЙ АКЦИИ «РИСУЕМ ПОБЕДУ»}

Аннотация. В статье рассматривается ход и результаты подготовки воспитанников ГБОУДО «ДДЮТ» г. Севастополь к участию во Всероссийской детско-юношеской акции «Рисуем Победу». Представляется механизм подготовки детей к участию в творческой акции, приводятся данные опросов, делается вывод о результативности применяемого подхода. Статья может быть полезна в качестве практического опыта работы учреждения в контексте сетевого Всероссийского проекта.

Ключевые слова: патриотизм, патриотическое воспитание, акция.

O. A. Bondar, Head of the Department of Decorative and Applied Arts and fine arts GBOUDO "DDYUT" Sevastopol'

Mitusova Yu. A., teacher of additional education GBOUDO "DDYUT" Sevastopol'

\section{FROM THE EXPERIENCE OF PREPARING PARTICIPANTS OF THE ALL-RUSSIAN CAMPAIGN "DRAW A VICTORY"}

Abstract. The article discusses the progress and results of the preparation of pupils of the State Educational Institution "DDUT" in Sevastopol to participate in the All-Russian children's and youth action "Draw a Victory". The mechanism of preparing children for participation in a creative action is presented, survey data are given, and a conclusion is made about the effectiveness of the approach used. The article can be useful as a practical experience of the institution's work in the context of a network All-Russian project.

Key words: patriotism, patriotic education, action. 
Подготовка детской аудитории к участию в значимом конкурсе, соревновании, фестивале всегда требует от педагога комплексного подхода и глубокого погружения в тематику предлагаемого мероприятия. Необходимо глубоко погрузится в теоретические и практические основы предлагаемого материала, структурировать его, продумать наиболее эффективный механизм информирования и вовлечения детской аудитории в процесс совместного изучения, осмысления и практической работы.

В этом ключе интересен и показателен опыт работы педагогов дополнительного образования Дворца детского и юношеского творчества города Севастополь по подготовке воспитанников к участию во Всероссийской детско-юношеской акции «Рисуем Победу» [1] в 2021 г.

Показателями педагогической эффективности этой работы могут служить конкретные практические результаты: 26 воспитанников творческих объединений «Страна Фантазий» и «Вдохновение» (педагог Ю. А. Митусова), в возрасте от пяти до 16 лет приняли активное и заинтересованное участие в Детско-юношеской патриотической акции.

Непосредственной творческой деятельности по созданию произведений изобразительного искусства на заданную тему, предшествовала глубокая работа по изучению темы победы в Великой Отечественной войне, знакомство с материалами сайта «Рисуем Победу» [2]. Содержащихся в нем методических рекомендаций и тематических презентаций.

Ребята очень трепетно и кропотливо создавали свои рисунки, кто-то рассказывает в своих работах о подвигах своих прадедов, некоторые отобразили в своих рисунках свой родной город - герой Севастополь, другие выбрали сюжет для своей композиции, как они всей семьей посещают парад Победы, с гордостью проносят фотографии своих прадедов. Другие с восхищением вспоминают незабываемый салют Победы.

В каждой работе воспитанников «живет душа». Дети сообщили, что гордятся великим подвигом своих родственников, своего города и своей страны.

Серьезным мотивирующим началом, было осознание сопричастности к масштабу проводимой акции, в которой приняло участие более полумиллиона юных россиян и их сверстников из государств СНГ, итоги которой были подведены 9 мая 2021 г., 531779 творческих работ юных авторов из 6 государств и 11586 населенных пунктов были поданы в этом году на участие в Акции. Каждый участник получил на память именной электронный сертификат, а компетентное жюри выделило 76 лучших работ, которые будут отмечены специальными дипломами. 
Славные подвиги поколения победителей отразили в своих рисунках и эссе не только юные россияне, но и их сверстники из Белоруссии, Казахстана, Армении, Таджикистана, Киргизии. Юным участникам Акции было предложено создать рисунок, а также, побеседовав со старшими написать небольшое эссе, повествующее о жизни родных и близких в годы войны. В текущем году отмечается невероятное разнообразие изобразительных средств и подходов. Трогательные детские рисунки появлялись в окнах домов, оживлялись мелом на асфальте, много было подано изделий декоративно-прикладного искусства.

В процессе творчества, на основе услышанного и осознанного исторического материала, участники были вовлечены в живой диалог поколений, узнали и осознали историю своей семьи и своей страны.

Куратор акции, депутата Государственной Думы России А. Аршинова отметила, что основная цель акции - сформировать и развить у детей и молодежи чувство патриотизма, уважения и сопричастности к славному ратному и гражданскому подвигу предков на основе творчества была достигнута. По мнению художественного руководителя акции В. Головачева, «текущий год показал невероятную вовлеченность в Акцию школ и детских садов, учреждений культуры и молодежной политики, семей, детей и молодежи.

Акция стала доброй народной традицией, связанной с празднованием Дня Победы». Организаторы решили не закрывать возможность подачи творческой работы на сайт акции и после подведения итогов. Это важно для тех, кто не успел принять участие, еще не получил памятный сертификат или обнаружил в своем сертификате ошибку.

Воспитанники ГБОУДО «ДДЮТ» г. Севастополь достойно представили свое учреждение и свой город-герой Севастополь. Из такого огромного количества и многообразия достойных работ: в средней возрастной категории - Л. Канивец («Страна Фантазий») стала лауреатом (второе место), с работой «Салют Победы».

Лида рассказала, что в работе «Я нарисовала как мы с родителями и сестрой, смотрим с набережной Корнилова, салют Победы. Он очень огромный, разноцветный и красивый. И я постаралась в своей работе, передать все свои незабываемые эмоции».

М. Охотина-Кровякова («Страна Фантазий») стала дипломантом, с работой «Мы Помним! Мы гордимся!» 
Мирослава рассказала о своей работе: «В своей работе я старалась изобразить, как мы посещаем Парад Победы, обязательно с фотографиями своих прадедов, чтобы почтить память про них. Так же при встрече с ветеранами, мы поздравляем их с праздником Победы! Это очень важный для нас праздник!»

Итоги участия воспитанников ГБОУДО «ДДЮТ» г. Севастополь показали большую заинтересованность и вовлеченность детской аудитории в совместное творческое изучение и осмысление историко-культурного материала.

\section{Литература}

1. Головачев, В. С. Всероссийская акция «Рисуем Победу» : методические рекомендации / В. С. Головачев, А. И. Аршинова // Чебоксары : Плакат, 2019. - 60 с.

2. Рисуем Победу [Электронный ресурс]. - URL: http://risuempobedu.ru/ (дата обращения: 02.07.2021). 
Научное издание

\section{НРАВСТВЕННО-ЭСТЕТИЧЕСКОЕ И ГРАЖДАНСКО-ПАТРИОТИЧЕСКОЕ ВОСПИТАНИЕ В ГОСУДАРСТВЕННЫХ УЧРЕЖДЕНИЯХ ОБРАЗОВАНИЯ И КУЛЬТУРЫ}

Отв. за выпуск В. С. Головачев

Компьютерная верстка В. Ю. Арестовой

Подписано в печать 05.09.2021.

Дата выхода издания в свет 05.10.2021.

Формат 60×90 1/16. Бумага офсетная. Печать офсетная.

Гарнитура Times. Усл. печ. л. 7,1. Заказ К-888.

Тираж 150 экз.

Издательский дом «Среда»

428005, Чебоксары, ул. Гражданская, 75, офис 12

+7 (8352) 655-731

info@phsreda.com

https://phsreda.com

Отпечатано в Студии печати «Максимум»

428005, Чебоксары, ул. Гражданская, 75

+7 (8352) 655-047

info@maksimum21.ru

www.maksimum21.ru 